Florida International University

FIU Digital Commons

$3-26-2020$

\title{
African Pentecostalism in America: a Study of a Nigerian Charismatic Church in South Florida
}

Uchenna Regina Onwumelu

uonwumel@fiu.edu

Follow this and additional works at: https://digitalcommons.fiu.edu/etd

Part of the Other Religion Commons

\section{Recommended Citation}

Onwumelu, Uchenna Regina, "African Pentecostalism in America: a Study of a Nigerian Charismatic Church in South Florida" (2020). FIU Electronic Theses and Dissertations. 4386.

https://digitalcommons.fiu.edu/etd/4386

This work is brought to you for free and open access by the University Graduate School at FIU Digital Commons. It has been accepted for inclusion in FIU Electronic Theses and Dissertations by an authorized administrator of FIU Digital Commons. For more information, please contact dcc@fiu.edu. 
FLORIDA INTERNATIONAL UNIVERSITY

Miami, Florida

\section{AFRICAN PENTECOSTALISM IN AMERICA: A STUDY OF A NIGERIAN \\ CHARISMATIC CHURCH IN SOUTH FLORIDA}

A thesis submitted in partial fulfilment of the

requirements for the degree of

MASTER OF ARTS

in

RELIGIOUS STUDIES

by

Uchenna Onwumelu

2020 


\section{To: Dean John Stack}

School of International and Public Affairs

This thesis written by Uchenna Onwumelu and entitled African Pentecostalism in America: A Study of a Nigerian Charismatic Church in South Florida, having been approved in respect to style and intellectual content, is referred to you for judgment.

We have read this thesis and recommend that it be approved.

Erik Larson

Iqbal Akhtar

Albert Wuaku, Major Professor

Date of Defense: March 26, 2020

The thesis of Uchenna Onwumelu is approved.

Dean John Stack

School of International and Public Affairs

Andres G. Gil

Vice President for Research and Economic Development and Dean of the University Graduate School

Florida International University, 2020. 


\section{ACKNOWLEDGMENTS}

Immeasurable thanks to the Almighty for His lovingkindness and mercies throughout the journey of graduate school. My gratitude goes to Chumdimdu, Angel Onwumelu, Chimsismdi, Stephanie Onwumelu, and Sochikayima Emmanuella Onwumelu, my beautiful creatures who their memories serve as the muse for success and inspiration. My deepest gratitude also to Mrs. Nchedo Onwuamaegbu, who her words of encouragement lingered in moments of loneliness. Professor Albert Wauku, Professor Erik Larson, Professor Akhtar Iqbal, I am grateful for your academic support throughout the entire program, especially during the period of research. I also appreciate Ms. Luz Aviles and Ms. Yusimi Sayus for the beautiful moments we shared in the office. I cannot forget Rev Ugochukwu Onyinnaya who made this research possible by granting me access to the area of study and encouraging members to participate and contribute towards my research. 
ABSTRACT OF THE THESIS

\title{
AFRICAN PENTECOSTALISM IN AMERICA: A STUDY OF A NIGERIAN
}

\section{CHARISMATIC CHURCH IN SOUTH FLORIDA}

\author{
by
}

\section{Uchenna Onwumelu}

Florida International University, 2020

Miami, Florida

\section{Professor Albert Wuaku, Major Professor}

In recent decades, there has been a rapid growth of African Pentecostal or Charismatic Christianity in the West and the United States of America. Researchers in this area have identified some of the roles that these African religious organizations paly in the diaspora. This research argues that African Pentecostals in diaspora not only serve the purpose of evangelism or proselytism but are also contexts for Africans to perform their identity and at the same time, serve as a connection between the diaspora and the homeland.

The study is fieldwork-based. Using performance and simultaneity as the theoretical leads, the Redeemed Christian Church of God, a Nigerian originated church in South Florida as a case, this research explores the activities of Nigerians in the United States and concludes that the church offers the context of a between and betwixt life for migrants. The church also creates the basis for their identity and cultural performance.

Date; March 26, $2020 \quad$ Time: 4pm

Place: MMC, DM 223 Department: Religious Studies 


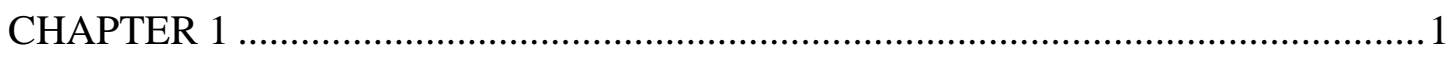

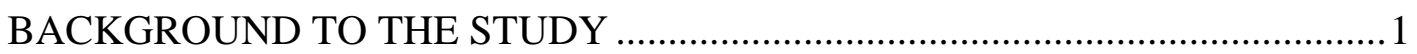

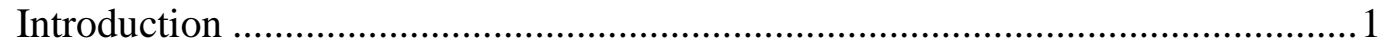

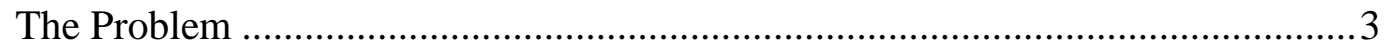

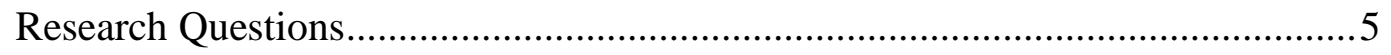

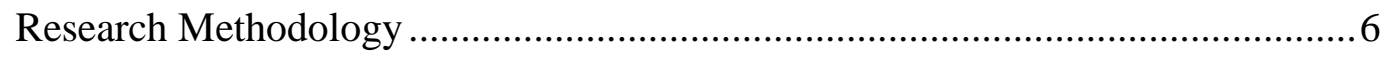

Findings and the Main Argument of the Study ............................................... 9

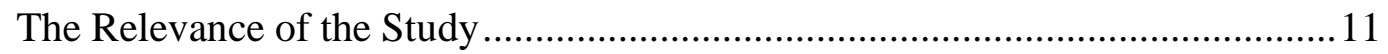

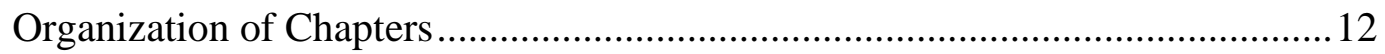

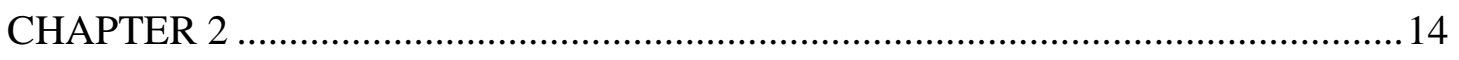

RELEVANT THEORETICAL FRAMEWORKS .............................................. 14

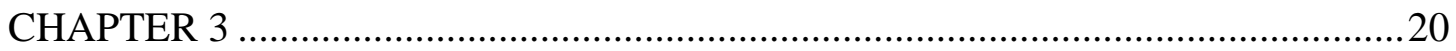

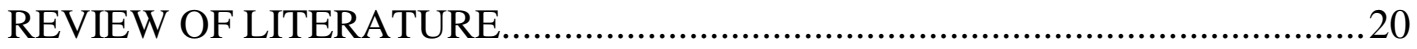

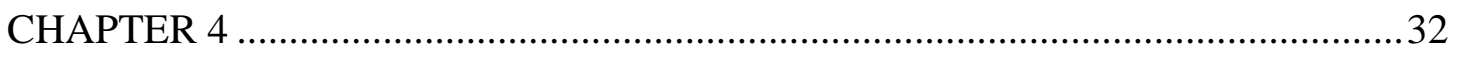

THE REDEEMED CHRISTIAN CHURCH OF GOD IN NIGERIA ..................... 32

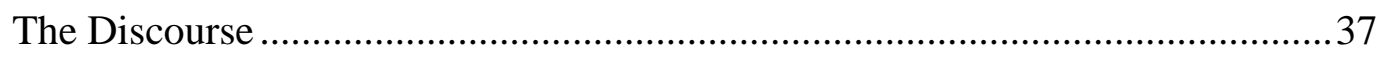

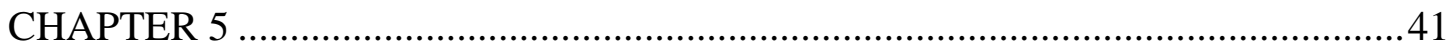

THE STORY OF THE REDEEMED CHRISTIAN CHURCH OF GOD IN MIAMI............................................................ 41

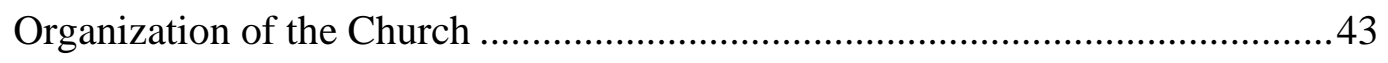

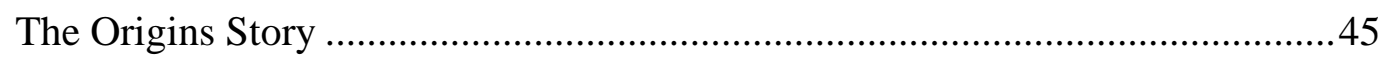

Making Ethnographic Sense of the Origins Story ........................................... 47

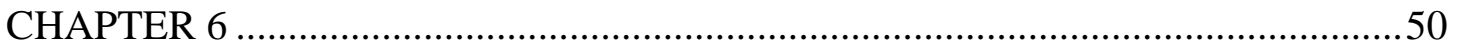

THE REDEEMED CHRISTIAN CHURCH OF GOD AS A PERFORMING GROUND 


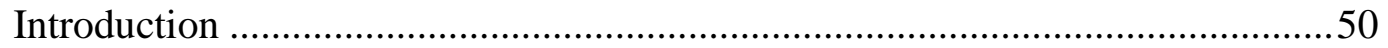

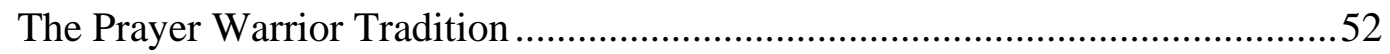

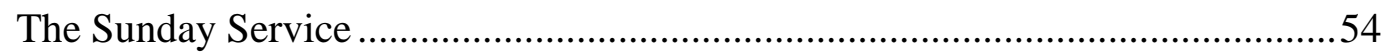

Healing and Deliverance Hour/ Service ..........................................................60

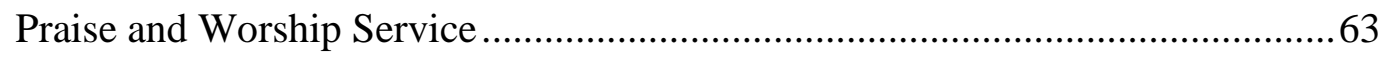

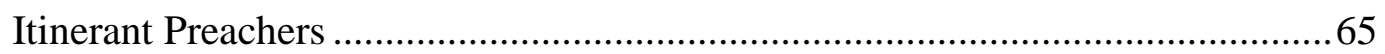

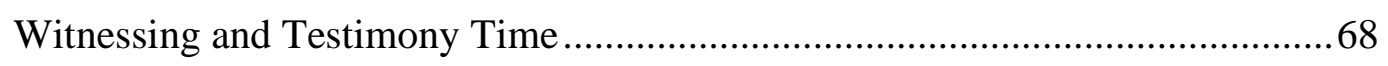

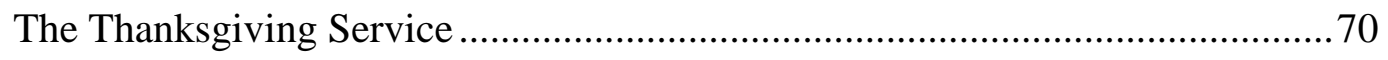

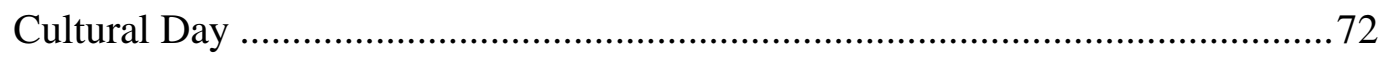

Early Morning Encounter with the Holy Ghost.............................................. 75

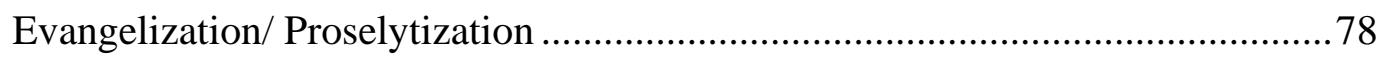

Child Dedication/ Funeral Assistance .......................................................... 82

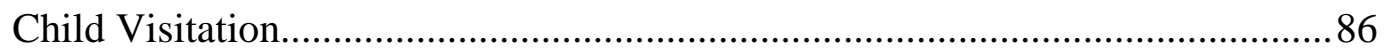

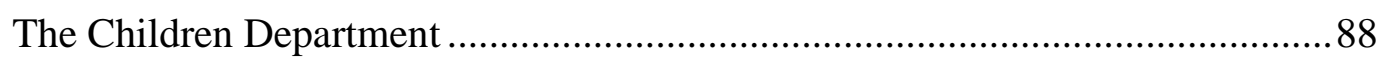

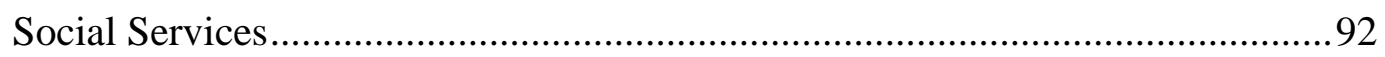

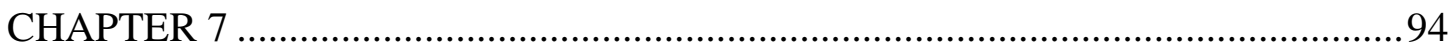

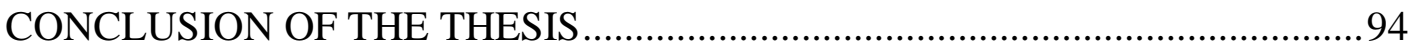

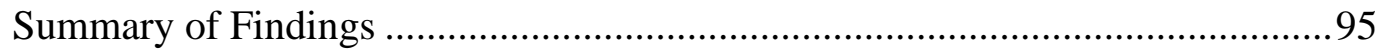

Bibliography...................................................... 97

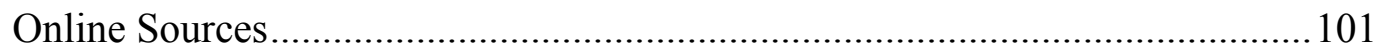




\section{CHAPTER 1}

\section{BACKGROUND TO THE STUDY}

\section{Introduction}

Changes in immigration policies coupled with current economic, social, and political difficulties in other parts of the world, have accelerated the pace of migration into the United States and the rest of the western world, particularly in the past few decades. As a result, the country has experienced a massive influx of newcomers from Latin America, Asia, and the Middle East. ${ }^{1}$ Immigrants from Africa have joined in this process. $^{2}$ According to a new study by the Pew Research Centre, "as of 2015, nearly 2.1 million people were living in the US who were born in Africa. The number is up from 880000 in 2000 and only 80,000 in 1970. Monica Anderson, a research associate and author estimates that the numbers are doubling approximately every decade and that this trend is continuing. ${ }^{3}$ In 1980, 1 percent of refugees admitted to the US were Africans, and today that share is about 37 percent. More importantly, her work also found that Nigerians make up the most significant African diaspora population in the United States with a population of 327, 000 followed by Ethiopia at 222, 000 and Egyptians at 192,

\footnotetext{
${ }^{1}$ Adogame, Afe. "Raising champions, Taking territories: African Churches and the Mapping of New Religious Landscapes in Diaspora." The African Diaspora and the Study of Religion (Palgrave Macmillan, New York, 2007), 17-34.

${ }^{2}$ Trost, T., ed. The African Diaspora and the Study of Religion. (Springer, 2007), 17.

${ }^{3}$ African Immigrant Population on Rise in US | Voice of America https://www.voanews.com/africa/african-immigrant-population-rise-us? src=voa-editor-picks pdf. Issued Jan.25 2015. Accessed Feb 4, 2020.
} 
$000 .{ }^{4}$ With the influx of new immigrants, Europe and the United States have also experienced a rapid increase of new religious communities and an expanding diversification in spiritual life. ${ }^{5}$

As an academic field of studies, the African diaspora has expanded considerably in recent years. The foci of the scholarship have been on political and socio-economic developments in the African diaspora with a growing emphasis on transmigration and the creation of new African diasporas. In the ever-increasing interconnection of localglobal spaces, contemporary migratory trends bring to the fore the crucial role religious symbolic systems play in new geo-cultural contexts. Through several case studies on immigrants, researchers have noted the importance of religion as a central element for ethnic and religious identity formation, reproduction, and maintenance ${ }^{6}$. Religious identity can also serve as an essential resource for the stimulating of a culture of origin in a host country, and the religious institution provides immigrants with opportunities for mixing with people from different cultural backgrounds under the umbrella of a common religion. When Africans migrate to the United States and elsewhere, they carry their religious identities with them. ${ }^{7}$ Also, often, their sojourn in a different geo-cultural context has encouraged these migrants to reconstruct, organize, and identify their

\footnotetext{
${ }^{4}$ African Immigrant Population on Rise in US | Voice of America https://www.voanews.com/africa/african-immigrant-population-rise-us?src=voa-editor-picks, Anderson, Monica. "A Rising Share of the US Black population is Foreign Born." Pew Research Center 9 (2015).

${ }^{5}$ Trost, T., ed. The African Diaspora and the Study of Religion. (Springer, 2007), 19.

${ }^{6}$ Ter Haar 1998; 1999, Ebuagh and Chaffetz 2000, Adogame 2003; 2005, Haddad et all 2003, Vasquez and Marquardt 2003 in Trost (eds) "The African Diaspora and the Study of Religion (Palgrave Macmillan, 2007), 18.

${ }^{7}$ Trost, T. (ed). The African Diaspora and the Study of Religion (Springer, 2007), 19.
} 
religion both for themselves and their host communities. Recent literature on African religious communities in Europe and the United States provides useful insights into the significance of the new African religious diaspora while pointing out the urgent need for more critical studies about the role of religion in the diaspora. ${ }^{8}$

This research aims to study the role played by the religious institutions, as well as their significant implications both for the community in diaspora and for the communities in the homeland, that is, Africa. As religious communities continue to burgeon and propagate in the diaspora, a deeper understanding of their role is appropriate. In a general sense, the objectives of the investigation on which this thesis is based are to examine these religious institutions in the diaspora and how they furnish the basis for diasporic groups' re-integration and identity renegotiation and also facilitate links between the diaspora and the homelands or points of origin of these groups. The specific focus of the investigation is a migrant Nigerian Pentecostal church in Miami. Using this church as one case, the project investigated the relevance of religion in the lives of Nigerian migrants in the USA. Particularly, it sought to answer this question: How and to what extent do African churches in the diasporic spaces they occupy in the United States of America, foster ethnic identities and link migrants whose life situations can be described as being "between and betwixt" to their homelands.

\section{The Problem}

The Redeemed Christian Church of God abbreviated as (RCCG), the case for this research, is a Nigerian-founded charismatic church in North Miami, Florida. The mother

\footnotetext{
${ }^{8}$ Adogame in Trost, T., (ed). The African Diaspora and the Study of Seligion, (Springer, 2007), 19
} 
or homeland church originated in Nigeria in 1952. The founder was Pa Akindayomi, an illiterate, who, according to a narrative was able to write down the name of the church which was revealed to him in English in a dream. He also received the mandate to expand the influence of the Church beyond Nigeria, during the revelation. ${ }^{9}$ Honoring the commission, the Redeemed Christian Church of God has expanded globally. There are at least 2000 parishes of this church in Nigeria. It also has a significant presence in other African nations, including Uganda, Zaire, Ghana, Tanzania, Malawi, to mention a few, and has also spread to Europe, Asia, and the Caribbean. ${ }^{10}$ One of the most popular destinations for African migrants is the United States, and The Redeemed Christian Church of God has its branches in several states in the United States, which includes Florida.

The Miami extension of the Redeemed Christian Church of God, the focus of this study, is 22 years old and has a membership of about 200 . While some members are from the Caribbean, Latin America, the African American community, and other African nations, the majority are Nigerians. For this reason, the Church's Pentecostalism culture is mainly Nigerian, with only slight adjustments made to accommodate the religious and cultural needs of the other ethnicities. The church also has links with itinerant pastors and heads of its branches in Nigeria, other African nations, and within the United States. Recent literature on African religious communities in the United States and Europe present valuable insights into the importance of the new African religious diaspora while

\footnotetext{
${ }^{9}$ Our History: The Redeemed Christian Church of God. http://rccg.org/who-we-are/history/. Last Accessed 01/07/2020.

${ }^{10}$ Our History: The Redeemed Christian Church of God. http://rccg.org/who-we-are/history/. Last Accessed 01/07/2020.
} 
pointing out the need for more critical investigations into the role of religion in contemporary African diasporic experiences. ${ }^{11}$ Informed by the leads this literature offers, this project's goal was to research, document, and analyze how the congregation of the Redeemed Christian Church of God in Miami provides for Nigerian migrants a context for creating and performing their identity and maintaining symbolic and direct links with their homeland, Nigeria. The questions below guided my research on the Redeemed Christian Church of God in Miami.

\section{Research Questions}

- What is the history of the Redeemed Christian Church of God in Miami?

- What does this church teach, and what are its practices?

- How do the activities and the discourse of the church foster a sense of being Nigerian among members, and how do members perform this identity?

- How does the church help members establish and maintain links with Nigeria, the homeland, and what do the Nigerian members say about the importance of these links?

${ }^{11}$ Adogame, Afe. "Raising champions, Taking territories: African Churches and the Mapping of New Religious Landscapes in Diaspora." The African Diaspora and the Study of Religion, (Palgrave Macmillan, New York, 2007), 17-34. 


\section{Research Methodology}

The research involved the use of religious ethnography as a significant method of data gathering. This method entailed participant observation, which required observation of the ritual forms and other activities of the Redeemed Christian Church of God at its base in North Miami. I also conducted interviews with the pastor, leaders, and members of the church to elicit information about the community's history, experiences of members, and the innovations it is making to shape itself to the ethos of its new home in Miami.

To gain firsthand experience of the church routine, I participated actively in the church's programs and activities internationally, ${ }^{12}$ and locally. I attended church services on Sundays and also participated in mid-week events like the youth meetings, prayer and healing services, thanksgiving services, to mention a few. My presence as a researcher at the large church gatherings was hardly noticeable as many people in the congregation took notes or made video recordings during the service. My regular taking of notes and video-recording of events did not betray my status as a researcher. Also, because I am a Nigerian who speaks Igbo and a few other Nigerian dialects fluently, I did not stand out as would a researcher of different racial backgrounds and color. Our common racial knowledge and everyday immigration experiences made most of the participants relate to me easily during the period of the research.

I was also involved in the regular online prayers and worship sessions that take place weekly. I witnessed special ceremonies performed in the church, such as thanksgivings,

\footnotetext{
${ }^{12}$ Participating internationally entails joining in the international programs of the church, which is done online, where members connect via website or code to participate.
} 
evangelism, outreach activities, and dedication/naming of children. While the primary site of the project was the church's base in North Miami, I participated in the daily lives of some Nigerian members through the visits I made to their homes. I also attended some of their social events.

The interviews aimed at eliciting from members, their views about how the church gives them a sense of being Nigerian in Miami, how it makes them feel connected to the homeland, and what this sense of being connected to the home country means to them. My approach was in keeping with Hammersley's suggestion that effective ethnography involves the researcher participating overtly or covertly in people's daily lives for an extended period, watching what happens, listening to what is said, and, or asking questions through informal and formal interviews, collecting documents and ${ }^{13}$ artifacts, in fact, gathering whatever data are available to throw light on issues that are emerging from the inquiry. ${ }^{14}$

He also notes how people's actions and accounts are studied in everyday contexts rather than under conditions created by the researcher, such as in experimental setups or highly structured interview situations. ${ }^{15}$ This is the reason why I used the unstructured method of questioning, which does not involve following a fixed and detailed research design. The informal interview approach was beneficial in eliciting useful information

\footnotetext{
${ }^{13}$ Jessica Maclaren, M. Nelson Heather Willinson and Liz Taylor. A Short Guide to Ethical Practice and Governance for Ethnographic Research with People who have Dementia, (University of Edinburgh, 2019),320.

${ }^{14}$ Hammersley, Martyn, and Paul Atkinson. Ethnography: Principles in Practice (Routledge, 2007), 3 .

${ }^{15}$ Hammersley, Martyn, and Paul Atkinson. Ethnography: Principles in Practice (Routledge, 2007), 3 .
} 
from selected individuals from different sub-groups within the church. The primary purpose of this was to ensure that data gathered proportionately represents that of the church in general, in that all the different subgroups are represented, that is, elders and deacons, the youth, the music and choir team, mothers and fathers, 'prayer warriors'(a group charged with the task of praying on behalf of the worshipping community), children, and young adults, etc.

While my presence at the large church services was hardly noticeable, it seemed invasive sometimes, especially in small group situations. As Lincoln and Denzin acknowledge, "interactive observers are by definition intrusive." 16 They also argue that objective observers and observations do not really exist because "any gaze filters through the lens of language, ethnicity, race, social class, and gender.” Therefore, they conclude that "all observations are socially situated in the worlds of, and between, the observer and the observed." ${ }^{\prime 17}$ I also engaged another method of primary data collection, which involved carefully engaging selected personalities in focus groups. This was to facilitate in-depth study and to gain an understanding of a lot of views that may not be released when interviewing respondents privately.

I aimed to observe and have a deep understanding of all activities in the Church. I documented my observations and the views of respondents through scribbles on paper and audio /video recordings. I also made use of the camera to capture some moments

16 Denzin, Norman K., and Yvonna S. Lincoln. "Introduction," in Norman K. Denzin and Yvonna S. Lincoln (eds), Collecting and Interpreting Qualitative materials. (London and New Delhi: Sage, 2003), 1-45.

${ }^{17}$ Denzin, Norman K., and Yvonna S. Lincoln. "Introduction," in Norman K. Denzin and Yvonna S. Lincoln (eds), Collecting and Interpreting Qualitative materials (London and New Delhi: Sage, 2003), 1-45. 
that spoke and gave meaning to my research. My notetaking and recording equipment did not call for special attention. This is because some church members write and record during church services, especially during sermons and meetings. My interviews took place in several sessions, and I engaged about thirty-five respondents. These include registered members and visitors to the church. Some of my interviews were informal in that they were what I would describe as casual conversations I had with members randomly. Loffland notes that, "the data collected in the field of research come through or are enhanced by informal interviews." 18 Needless to say, such informal interviews were mostly useful throughout the fieldwork.

I also consulted various primary and secondary sources that offered information on the church, its history, and experiences. These included invitation flyers, church pamphlets, posters, online materials, and magazines that advertised special church programs. The research also engaged relevant literature on African originated traditions rooted in Nigeria, the United States, and Europe, that shed light on the Redeemed Christian Church of God, its activities, and the experiences of its members in Miami.

\section{Findings and the Main Argument of the Study}

The themes below sum up my findings from the fieldwork on the Redeemed Christian Church of God in North Miami. I discovered that the Church's origins links with the overseas expansionist agenda of the Nigerian based mother church. ${ }^{19}$ As a result of this agenda, the Redeemed Christian Church of God is present in many parts of the world,

\footnotetext{
${ }^{18}$ Lofland, John, and Lyn Lofland. "H.: 1995, Analyzing Social Settings: A guide to Qualitative Observation and Analysis" (Belmont, CA: Wadsworth, 1995), 10.

${ }^{19}$ Our History: The Redeemed Christian Church of God. http://rccg.org/who-we-are/history/. Last Accessed 01/07/2020.
} 
including South Florida. However, establishing the church in Miami was also a result of the call from Nigerian migrants living and working in Miami. Having migrated to Miami, members of the community needed a place to worship as they did not feel at home in the American established religious institutions they first attended. They initially began a house fellowship, but later reached out to the headquarters in Nigeria and expressed their desire to have an RCCG branch established for them. But this move was also a part of the community's effort to re-integrate in their new home, Miami, using a common symbol -a religion.

The establishment of the Church has not only made it possible for Nigerian migrants to find a place to worship but to gather together periodically and participate in rituals and other events that make them feel united as Nigerians. More importantly, the Church also furnishes for these migrants a context for carrying out aspects of their culture, helping to create and nurture a shared sense of being together, or communal identity, in the process. The church hosts ritual agents from Nigeria and other Nigerian diasporas. They come with news of happenings in Nigeria and other diasporas. So, members feel they are still linked with and share in the experiences of the homeland and the global community of Nigerians.

On the basis of these themes, my thesis in this study is that the quest for Nigerian migrants to create a space to re-integrate as a migrant group and perform a pan-Nigerian identity coincided with the mission of the church in Nigeria to extend beyond its national boundaries. Church offers a space for Nigerian migrants in Miami to create and perform their identities as Nigerians in practical and symbolic ways. The church achieves these by providing for Nigerian migrants a framework for the transportation and implantation of elements of Nigerian Pentecostal traditions and beliefs (which embody cultural 
elements from many Nigerian ethnic groups) in the United States and these activities contribute to creating for these migrants something of "a home away from home" in the diaspora. Nigerian migrants, therefore, feel that they are neither in Miami nor in Nigeria entirely. They live their lives between and betwixt these two communities. The church furnishes Nigerian migrants in Miami with a context that bridges the divide they would otherwise feel.

\section{The Relevance of the Study}

Although scholarship on the subject of the African diaspora has grown considerably in recent years, the earliest phase of migration dominates the literature. Until recently, the second phase of the African diaspora, which is the contemporary phase of African movement, has not attracted much scholarly scrutiny. ${ }^{20}$ Religious institutions play a crucial role in diaspora communities, yet, a study of the comprehensive African diasporic and migration scholarship reveals a lack of theoretical and methodological reflection of its role in the context of present-day diaspora and migration studies. ${ }^{21}$ People carry their religious identities when they migrate. African migrants are no exception; in the United States, they reconstruct and re-organize these identities both for themselves and their host communities. Recent scholarship on African religious communities in Europe and the United States offer valuable insights into the importance of the new African religious diaspora while pointing out the need for more critical

\footnotetext{
${ }^{20}$ Adogame, Afe. "Raising Champions, Taking territories: African Churches and the Mapping of New Religious Landscapes in Diaspora." The African Diaspora and the Study of Religion (Palgrave Macmillan, New York, 2007), 17-34.

${ }^{21}$ Trost, T., (ed). The African Diaspora and the Study of Religion (Palgrave Macmillan New York, 2007), 17.
} 
investigations into the role of religion in contemporary African diasporic experiences. Regarding this, Adogame notes that "the task undertaken by religious institutions has implications both for the community in diaspora and for the religious communities in the homeland, that is, Africa. ${ }^{22}$

This research, therefore, adds to scholarship by demonstrating the critical role religious symbolic systems play in the diaspora. Using the Redeemed Christian Church of God, a Nigerian Pentecostal church in Miami, this study contextualizes the place of religion as a driving force of African diaspora formation and establishing a transnational space between the host countries and homeland. This research is immensely significant in evaluating how religious identity can serve as a vital resource for stimulating the culture of origin in a host country, which at the same time offers a context for immigrants to live a between and betwixt life.

\section{Organization of Chapters}

The thesis is organized into seven chapters. The first chapter offers a general introduction of the research and includes the introduction, the objective of the study, research questions, problem statement, methodology, and relevance of the study. The second chapter discusses the theoretical frameworks that were useful in the interpretation of the data collected. The third chapter reviews related relevant literature. The fourth chapter explores the Redeemed Christian Church of God, the case for the study. The fifth chapter explores the origins of the Redeemed Christian Church of God

\footnotetext{
22 Trost, T., (ed). The African Diaspora and the Study of Religion (Palgrave Macmillan New York, 2007), 18.
} 
in Miami. The sixth chapter explores the various ways in which the church offers context for performance for Nigerians in Miami. The final chapter concludes the thesis. 


\section{CHAPTER 2}

\section{RELEVANT THEORETICAL FRAMEWORKS}

This chapter discusses concepts relevant in understanding the Redeemed Christian Church of God, its religious activities, and significance for Nigerian migrants in Miami, theoretically. In developing the themes that run through the chapters of the study, two concepts will need to engage our reflection. I will analyze these concepts on their own, but will also examine them in terms of how they interact as they provide the framework for understanding the story of the Redeemed Church and its activities in Miami, and the lives of the Nigerian migrants involved, as parts of a coherent whole. The concepts are performance and simultaneity.

I will commence with a discussion of the performance theory. We can define performance as an act or process of carrying out or accomplishing an action, task, or function. It involves staging or presenting a play, concert, or different forms of entertainment. The theory of performance originates from a variety of disciplinary fields. However, it is most associated with Victor Turner and Richard Schechner. ${ }^{23}$ These authors studied the performative nature of societies around the world. Primarily their foci were how events and rituals, as well as the daily lives of people, are governed by codes of performance. Richard Schechner and Victor Turner identified two categories of performance: artistic and cultural performances. Artistic performance includes art forms such as solo-performances, performance art, the performance of literature,

\footnotetext{
${ }^{23}$ Turner, Victor Witter, and Richard Schechner. The Anthropology of Performance (New York, PAJ Publications, 1988), 6. Schechner R. Between Theaters and Anthropology, 1988.Schechner, Richard. Between Theaters and Anthropology (Philadelphia: Pennysylvania UP, 1985), 5.
} 
theatrical storytelling, plays, and poetry performance. These categories consider performance as art. Cultural performances are events that occur in everyday life in which cultural values are displayed, often, for their perpetuation. Rituals such as parades, political and religious ceremonies, community festivals, performances of literary, legal, social, and professional roles, some kinds of language use, and individual performances of sexuality, gender, race, and class are examples of cultural performances. From the ethnographic studies, Richard Schechner and Victor Turner did among different societies they highlight how performances are central to the understanding of human nature.

Performance theory suggests that every one of us puts on a performance in society, whether through the clothes we wear, the conversations we hold or the food we eat. ${ }^{24}$ Performances are designed as a signal system to us and others of our place within our social group. ${ }^{25}$ Scholars such as Derrida and Butler have also sought to understand the way performances reinforce and communicate our identities in society. ${ }^{26}$ Butler notes that when a person acts, he implicitly requests his observers to take seriously the impression that is fostered before them. ${ }^{27}$

The theory of performance offers valuable leads in understanding the importance of rituals of the Redeemed Church of God in Miami as religio-cultural performances. I

\footnotetext{
${ }^{24}$ Institute for Public Understanding of the Past, Performance and performativity https://archives.history.ac.uk/1807commemorated/media/methods/performance.html.
}

${ }^{25}$ Goffman, E. The Presentation of the self in Everyday Life (London Allen Lane, 1985), 28.

- $\quad{ }^{26}$ Derrida, J. Limited Inc. Translated by E. Weber. Paris. Éditions Galilée and Butler, J. Excitable Speech: the politics of the performative (New York, London. Routledge, 1997), 23.

${ }^{27}$ Butler, Judith, and Kirt Charles. Excitable Speech: A Politics of the Performative. (Psychology Press, 1997), 69. 
argue that by participating in the rituals of this migrant Church, Nigerian migrants act out their varied Nigerian understandings of ways of being in the world. In other words, the rituals and other instituted practices of the Church offer worshippers the opportunities to demonstrate their Nigerian identities in concrete ways. In diasporic contexts, migrant groups with common geographical origins use religion as the vital symbol of integration in their efforts to re-aggregate in their destination points. This is exactly what the Nigerian community in Miami did.

However, migrant identities are not only created within the religious space furnished by migrants' religious groups. Identities are also demonstrated through the ritual forms the Church has established. Although the Redeemed Church of God is a Pentecostal, and for that matter, a Christian tradition, its ritual culture is heavily inflected with Nigerian indigenous religious understandings and practices, enabling worshippers to demonstrate their being Nigerian through their participation in them. The study will show that some rituals of the Church that furnish contexts for performing aspects of Nigerian culture are indeed diasporic "inventions" designed to speak to the emerging needs of these migrants as they try to adapt to the new life situations the ethos of their new home, Miami, imposes on them. In this way, these Nigerian cultural productions taking shape within the Church do not only intend to demonstrate the "Nigerianess," of the Church. They are also pressed into service in the resolution of members' practical day to day issues in Miami.

I turn my attention to the next concept that this thesis engages, the concept of Simultaneity. Schiller and Levitt use this concept to capture situations in which "migrants and their descendants remain strongly influenced by their continuing ties to 
their home country or by social networks that stretch across national borders." 28 The assumption is that migrants seldom assimilate properly into their receiving contexts. As a concept, simultaneity helps us to see how we cannot understand the day-to-day lives of migrants fully when we assume that these lives are lived only within the national boundaries of their destinations.

The concept directs our attention to how cultural traits, values, and forms of physical interactions with their homelands shape the totality of the migrants' lives. In other words, migrants are involved in a multi-sited transnational social field. They, for instance, send remittances to family members or relatives in the homeland, engage in prayers or other religious activities on behalf of the homeland, and continue to fulfill other social or financial responsibilities or obligations towards the motherland. Simultaneity describes a scenario that is very typical of migrants from third world countries to developed or Western countries. Valentina Mazzucato, notes how such an engagement "enables linkages between dispersed people to tighten, new livelihood opportunities to emerge, social institutions to change, and hybrid identities to develop."29

Levitt makes a crucial point when he notes that while migration scholars generally acknowledge the importance of migrants' social, economic, political, and transnational activities, they have, to a great extent neglected how religious identities

\footnotetext{
${ }^{28}$ Levitt, Peggy, and Nina Glick Schiller. "Conceptualizing simultaneity: a transnational social field perspective on society 1." International Migration Review 38.3 (2004): 1002-1039.

${ }^{29}$ Peggy Levitt \& Nina G. Schiller, "Conceptualizing Simultaneity: A Transnational Social Field a Perspective on Society" International Migration Review 38:4 (2004), 1002. 24 Valentina Mazzucato, "Bridging Boundaries with a Transnational Research Approach: A Simultaneous Matched Sample Methodology" in Muilti-sited Ethnography, ed. M.A Falzon (Farnham, MA: Ashgate, Forthcoming), 216.
} 
and practices also enable migrants to sustain memberships in multiple locations. ${ }^{30}$ His reference here is to the participation of migrants in these diasporic and homeland worlds simultaneously through the practice of religion. One goal of the project on which this thesis is based was to help fill up this gap by demonstrating how the Redeemed Christian Church of God in Miami offers a religious context that enables its Nigerian members in Miami to participate in Nigerian culture and become involved in the affairs of Nigeria at the same time. Recent research on religions involved in global circulations brings into view how these religious traditions and their institutions establish international connections that create universal identities. Speaking to this development, Beyer alludes to the notion of simultaneity when he argues that migrants use religious institutions to live their transnational lives because often, religion is a global societal system that is transnational in its operation. ${ }^{31}$

This study argues that religious institutions are one of the agents of cross border connections. They provide the migrants' grounds to perform their identity, become who they are, and at the same time, create avenues for linkages between them and the people in the homeland. Following the leads offered by the concept of simultaneity, the study will show how the Redeemed Church of God provides opportunities for Nigerian migrants to continue to participate in the affairs of the homeland, through prayers, remittances, discussions on essential happenings in Nigeria, etc.

\footnotetext{
${ }^{30}$ Levitt, Peggy. "'You know, Abraham was really the first immigrant": Religion and transnational migration." International migration review 37.3 (2003): 847-873.

${ }^{31}$ Beyer, Peter, (ed). Religion in the Process of Globalization. Vol. 10. Ergon, 2001.
} 
While Levitt and Schiller emphasize the participation of migrants in the lives of their homelands, we will see in this study that this participation is a two-sided one; that is, people in the homeland also extend their activities into the various diaspora. For example, in terms of people's mundane affairs, relatives of migrants support them financially, socially, or through other means from the homeland. Government officials from the homeland also extend their activities to fellow countrymen in the diasporas. We will see how agents of religion in Nigerian are also able to extend their activities to the Miami portion of the Nigerian diaspora through their itinerant preaching activities.

The Redeemed Church of God hosts many of these preachers annually. Not only do they bring news of events in Nigeria, they also bring greetings from relatives, and a sense of familiarity to Nigerians in Miami. As they go back home, members of the congregation also send messages, news, money, etc. through these preachers to individuals and institutions back in Nigeria. One of the key themes in this thesis is that religious praxis provides a congenial context for these forms of simultaneous participation of migrants in both worlds.

I engage these two understandings of simultaneity in this thesis, especially in Chapter 6 where I explore how rituals of the Redeemed Church of God enable Nigerian migrants to participate in the lives of their kin back in the homeland and vice versa. Linked together, the theory of performance and simultaneity will enable us to conceptualize how the religious culture of the Redeemed Church of God offers opportunities for Nigerian Migrants in Miami to perform "Nigerianess" and generate moods that make them feel at "home" while living in far-flung Miami, or to encounter religious agents visiting and bringing home to them in the diaspora or taking symbols of life in the diaspora back to the homeland. 


\section{CHAPTER 3}

\section{REVIEW OF LITERATURE}

In this chapter, I review the relevant literature on African Pentecostal churches generally, but more specifically, their extension into the African diaspora and the roles they are playing in these spaces. The goal is to identify the relevant emerging themes in the growing body of writing on African Pentecostalism I can build on in my own study, as well as the gaps my study on the Redeemed Christian Church of God in Miami can hopefully fill. The Pew Forum estimated that as of 2006, at least one-quarter of the world's two billion Christians are part of the Pentecostal movement, ${ }^{32}$ with a significant number being Africans.

The research also shows how in recent decades, numerous African religions have appeared in Europe and the United States. ${ }^{33}$ Adogame identifies three trajectories underlying this emergence. He writes about churches that exist in the diaspora as branches of a mother church with headquarters in Africa. He also notes churches founded by new immigrants in the United States and Europe. This group often have their headquarters in Europe and the United States and then expands to Africa and beyond later. The last trajectory involves para-churches and interdenominational ministries with flexible, not formalized frameworks in which freelance missionaries embark on frequent visits to a network of churches overseas under the rubric of evangelism and interreligious

\footnotetext{
${ }^{32}$ Pew Research Center. "Religion and Public Life" https://www.pewforum.org/2006/10/05/spirit-and-power/ . Accessed Feb 2, 2020.

${ }^{33}$ Adogame, Afe. "Contesting the Ambivalences of Modernity in a Global Context: The Redeemed Christian Church of God, North America." Studies in World Christianity 10.1 (2004): 25-48.
} 
networks. ${ }^{34}$ The Redeemed Christian Church of God, the focus of this research can be categorized under the first trajectory. The Church is headquartered in Africa and exported to the United States and Europe. Referring to this trajectory, Bruni notes, "Christianity has boomed in the developing world, now competing successfully with Islam with deepening influence and possibly locating its future in Europe."35

A theme in the burgeoning literature on African religious bodies across and beyond Africa is the motives for the proliferation of these religions globally. Some scholars see this growth of African Pentecostalism in America as a 'mission in reverse,' a case where Africans say they want to export their brand of Christianity and ethical discipline to the United States, a country they believe has lost its fervor. ${ }^{36}$ Studying the reverse mission agenda, Adogame looks at the connection between the migrant communities in the diaspora and the religious communities in the homeland. He noted that "Many African churches in the homeland are now consciously involved in sending missionaries to evangelize Europe, the United States and other parts of the world, supporting and financing them. ${ }^{37} \mathrm{He}$ also pointed out one characteristic of religion in North America, which is the ethnic dimension of denominationalism. This view is important for this study. The reverse mission paradigm partially explains the presence of the RCCG in North Miami.

\footnotetext{
${ }^{34}$ Adogame in Trost 2007, 20

${ }^{35}$ Bruni, Frank. "Faith Fades Where It Once Burned Strong." New York Times (2003): 1-7.

${ }^{36}$ The African Diaspora and the Study of Religion (Religion .... https://epdf.pub/the-africandiaspora-and-the-study-of-religion-religion-culturecritiquea43100f86a025c4e62932e 345d06477735110.html
}

\footnotetext{
${ }^{37}$ Adogame, Afe. "Raising champions, taking territories: African churches and the mapping of new religious landscapes in diaspora." The African diaspora and the study of religion. Palgrave Macmillan, New York, 2007. 17-34.
} 
McCann and Lieblich note that "American missionaries brought Christianity to Africa. Now Africans want to export their brand of religion, which is ecstatic, to the United States with the hope of teaching moral discipline, which they think the country has lost. ${ }^{38}$ Other scholars note how African Prophetic and Independent Churches seek to use American cities as the bases from which they can expand globally. ${ }^{39}$ Churches such as the RCCG show how the motives for expanding overseas can be rooted in the spiritualities of these African Churches.

The mandate of this church concerning the establishment of churches in Nigeria, African nations, and the world over is based on the covenant that the leader of the church supposedly had with God when he was charged with the responsibility of leading the church in a dream. ${ }^{40}$ In view of the transnational flows, it is involved in Pentecostalism and currently being characterized as a global phenomenon. Some scholars argue that it is the fastest-growing Christian movement globally. Walter Hollenweger describes the growth as miraculous as he traces it from zero to almost five hundred million in less than a century. $^{41}$

The history of Pentecostalism in North America, as well as many parts of the world where it has established its roots and branches, is also a subject of debates. Anderson notes how this movement originated from the Azusa Revival of 1906 in Los

\footnotetext{
${ }^{38}$ Lieblich, Julia, and Tom McCann. "Africans Now Missionaries to US." Chicago Tribune (2002): 1.

${ }^{39}$ Irvin, Dale. "A review of the next Christendom: The Coming of Global Christianity by Philip Jenkins." Journal of Pentecostal Theology 13.2 (2005): 273-280. Also, Trost 2007, 21

${ }^{40}$ RCC Website https://www.samford.edu/news/2018/10/Adeboye-Head-of-WorldwideRCCG-Church-To-Speak-at-Samford
}

${ }^{41}$ Hollenweger, Pentecostalism, p. 1; see Anderson, Varieties, Taxonomies,' pp.13-29; Anderson, To the Ends of the Earth, pp. 4-9. 
Angeles in the United States. ${ }^{42}$ However, scholars like Kalu and Wacker challenge this position arguing that Pentecostalism, especially the African portion has been represented with a biased history. Wacker refers to this bias as "a ritualization of Pentecostal history which included a white racial bias that ignored the significant influence of black culture on Pentecostal worship and theology."

Kalu sees it as stupendous to claim that all Pentecostal outside North America trace their genealogy to Azusa Street and argues that Charismatic movements worldwide often occur without "missionary catalytic sparks." 44 Following this line of thinking, some scholars have noted how the biased records of the Western institutions and their leaders presented a misleading foundation for understanding how African Pentecostals developed independently from Western missionaries. They note how biases and presuppositions always influence the writing of history, and the literature on the Pentecostal history of Africa, Asia, and Latin America is no exception. ${ }^{45}$ This debate points to the diversity in Pentecostal forms and history.

Another important theme is the interconnectedness of African Pentecostalism, migration, and diaspora, especially in North America. Speaking to the novelty of this development Adogame notes, "if previously African religions were group tied, today African religions are practiced by a remarkably diverse range of people outside the

\footnotetext{
${ }^{42}$ Anderson, An introduction to Pentecostalism, 2014, 9.

${ }^{43}$ Wacker, Grant. "Are the Golden Oldies still worth playing? Reflections on history writing among early Pentecostals." Pneuma 8.1 (1986): 81-100.

${ }^{44}$ Kalu, African Pentecostalism, 2005, 13-15.

${ }^{45}$ An Introduction to Pentecostalism: Global Charismatic Christianity (2004), 167-184 and 'Revising Pentecostal History in Global Perspective', in Anderson and Tang (2004), pp.157183.
} 
continent. ${ }^{46}$ Emphasizing this new flow, Adogame writes, "Religious traditions that were embraced by Africans are now repackaged and Africanized and exported to new environs. ${ }^{47}$ Referring to African Christianity in his work Of Africanized Bees and Africanized Churches: Ten Theses On African Christianity, Maluleke locates his analysis of the flow of African Christianity outside the continent in a broader context, that is, global Christianity. He argues that although geography cannot be dismissed,

African Christianity is not merely about the Christianities happening within the confines of the African continent, African Christianity is to be found wherever African people are present, have a presence, or have influence. This includes the global South, as well as Europe and North America. He added that "African Christianity is not merely about people of African descent or origin, but about a way of being Christian that takes dialogue and context seriously. He concludes that African Christianity is indeed a form of Christianity all over the globe; therefore, no longer about skin color, origins, and geographical locations of its practitioners." 48

Mulakale's analysis is significant in identifying this form of Christianity as African. He alludes to the participation of categories that cannot be described as African in this form of Christianity. Sharing Maluleke's perspectives, Jacob Olupona demonstrates how African religions have spread far and wide. Olupona and Gemignani

\footnotetext{
${ }^{46}$ Adogame, Afe. "“I am married to Jesus"! The feminization of new African diasporic religiosity." Archives de sciences sociales des religions 143 (2008): 129-149.

${ }^{47}$ Chitando, Ezra, Afe Adogame, and Bolaji Bateye. "Introduction: African Traditions in the Study of Religion in Africa: Contending with Gender, the Vitality of Indigenous Religions, and Diaspora." African Traditions in the Study of Religion, Diaspora and Gendered Societies. Routledge, 2016. 15-24.

${ }^{48}$ Maluleke, Tinyiko Sam. "Of Africanised Bees and Africanised Churches: Ten Theses on African Christianity." Missionalia: Southern African Journal of Mission Studies 38.3 (2010): 369-379.
} 
bring to the fore the nature and rise of African Christianity and where they fit in the interpretations of American religiosity. Issues such as geographic, political, social, and economic facilitating African migration. They show how African religious institutions play important roles in the immigrants' adaptation and the impact of immigration on them. The fact that they refer to African sojourners is instructive. ${ }^{49}$ This offers some leads that are helpful in this study. One lead is the idea that African migrants seldom view themselves as permanent settlers in the destination point. They still feel connected to their homelands and use religion as a way of linking with the homeland or participating in the affairs of the homeland in the diaspora.

In her fieldwork analysis of West Indies immigrants living close to the black neighborhoods in the USA, McLean highlights the various ways in which immigrants seek to set themselves apart by creating what she refers to as a "separation." This group socially "separate" themselves with the formation of social organizations, especially religious ones in which immigrants would occupy leadership positions and discover ties to job opportunities and interlacing ties which emphasize parental authority and moral values. ${ }^{50}$ This study also offers leads that help our research on Nigerian migrants and religious practice. We will see that although Nigerian migrants have access to other religious forms in Miami, they seek their "own" practice as a way of separating themselves from other African ethnicities in the city.

\footnotetext{
${ }^{49}$ Murrell, Nathaniel Samuel. "African Immigrant Religions in America." Journal of African American History 93, no. 3 (Sunner 2008): 463-65.

http://search.ebscohost.com.ezprozy.fiu.edu/login.aspx?direct=true \&db=hus\&AN=50991346\& site=eds-live.

${ }^{50}$ Waters, Mary C. "Ethnic and racial identities of second-generation black immigrants in New York City." International Migration Review 28.4 (1994): 795-820.
} 
Some scholars of Pentecostal Christianity use studies of particular African religious congregation, denominations, or African countries to make broad generalizations about their various roles. ${ }^{51}$ However, some scholars contend that bringing case studies from different countries and comparing across contexts is very useful, especially as it helps in more grounded empirical generalizations. ${ }^{52} \mathrm{I}$ do not intend to make sweeping generalizations based on this particular study. I believe that in a different geographical location a Nigerian Pentecostal tradition might behave in a different way.

Understanding the characteristics of the Nigerian worldview is essential in comprehending the performances of Nigerians/Africans in the Redeemed Christian Church of God. Examining the socio-historical origin of Nigerian Wariboko pays particular attention to four influential sources; personalities, cultural-historical antecedents, growth, and discourse, and demonstrates the embeddedness of Pentecostalism in the ethos of time and place, that is, Nigeria in the last one hundred and twenty-five years. Wariboko describes the experiences of believers, which supply the energy and goal of Pentecostalism, as well as the fluidity of African culture, its transversal interactions between physical and spiritual realms, "the social and political factors that determine the packaging, presentation, and form required by the deeply braided dynamics of divinity and African humanity. ${ }^{, 53}$ Nigerian Pentecostal spirituality

\footnotetext{
${ }^{51}$ Van Dijk, Rijk A. "From Camp to Encompassment: Discourses of Transsubjectivity in the Ghanaian Pentecostal diaspora." Journal of religion in Africa 27.Fasc. 2 (1997): 135-159.

${ }^{52}$ Elphick, Richard. "Christianity in Africa in the 1990s." International Bulletin of Mission Research 21.4 (1997): 183. Ganiel, Gladys. "Pentecostal and charismatic Christianity in South Africa and Zimbabwe: A review." Religion Compass 4.3 (2010): 130-143. See also, Burgess, Richard. "Pentecostals and Political Culture in Sub-Saharan Africa: Nigeria, Zambia, and Kenya as Case Studies." Global Pentecostal Movements. Brill, 2012. 15-42.

${ }^{53}$ Wariboko, Nimi. Nigerian Pentecostalism. Vol. 62. Boydell \& Brewer, 2014.
} 
is a continuous strategic exploration of how worshippers construct, represent, and sustain in a Christian context, the epistemological differences between the visible and invisible. Nigerian Pentecostalism is preoccupied with the unseen. The connection with the domain of the miraculous, the pursuit for unlimited access to divine grace as the source of magico-religious power, the assumption that the self emerges from the interaction between the invisible and the empirical world, and the attribution of causality to forces beyond the material and the phenomenal, all of which are features of Nigerian Pentecostalism are rooted in the Nigerian indigenous religious worldview. ${ }^{54}$

To the Nigerian Christians, there is this humanistic belief that ill-luck is caused by wicked spirits of the evil intention of human beings, and Christianity is the only remedy. In Nigeria and Africa in general, witchcraft and sorcery are potent concepts that acquire substantial attention in both economic and political arenas, as well as in religion and ritual. ${ }^{55}$ The Nigerian Pentecostal churches work with the African indigenous worldview of linking and translating local belief in demonology. They see every aspect of life to be controlled by the spiritual and the devil and place themselves as providing an avenue for escape through various activities that they provide. Through redemption, repentance, renunciation prayer, and sacrifice, human beings are men are liberated. ${ }^{56}$

Similarly, writing about the origins of Nigerian Pentecostalism, Pius Okpong notes how the situation of the Nigerian society in the early twentieth century was a major

\footnotetext{
${ }^{54}$ Wariboko, Nimi. Nigerian Pentecostalism. Vol. 62. Boydell \& Brewer, 2014, 18.

${ }^{55}$ Knut Rio, Michelle and Blanes, Introduction to Pentecostal Witchcraft and Spiritual Politics in Africa and Melanesia", Contemporary Anthropology of Religion, 2017.

${ }^{56}$ Ayuk, Ayuk Ausaji. "The Pentecostal Transformation of Nigerian Church Life." Asian Journal of Pentecostal Studies 5.2 (2002): 189-204.
} 
contributing factor to the spiritual awareness and the emphasis placed in the power of the Holy Spirit. This period witnessed extreme poverty and terrifying ailments coupled with the belief in an intense presence of witchcraft and demons in the society. Praying to the Holy Spirit was seen as the immediate and the only way of combating evil. ${ }^{57}$

According to Isichei, these adherents, "craved as they had always done, physical and spiritual healing, and protection from the multitude of evils against which the poor are powerless. When African prophets arose, who spoke to these needs from the depths of their religious consciousness, they counted their converts in hundreds of thousands." 58 As the focus of this study is a diasporic extension of a Nigerian Christian form, these insights are indeed very helpful. Migrants live on the margins of their destination points and face a myriad of problems linked to their settlement in a new world. The insights offered by these authors offer us valuable leads in understanding how the Nigerian migrants in these studies made sense of their migration experiences and why they prefer a Nigerian Pentecostal form to any other religion in Miami.

The increasing literature on African Pentecostalism has explored how some of the churches in Nigeria and Africa, in general, undertake to take the gospel across the continent, especially in the United States and Europe. Migration has been identified as having a link with the proliferation of new and expanding diasporic Nigerian religious communities. ${ }^{59}$ As Nigerian people migrate, they carry their religious identity with them

\footnotetext{
${ }^{57}$ Ukpong, Donatus Pius. "The presence and impact of Pentecostalism in Nigeria." Posted online at: www. glopent. net/.../presence-and-impact-of-pentecostalism-in-nigeria (2006).

${ }^{58}$ Isichei, Elizabeth. A history of Christianity in Africa: From Antiquity to the Present. W. B. Eerdmans Publishing, 1995, 179.

${ }^{59}$ Adogame in Trost 2007, 19
} 
as religious institutions offer them the context for social, economic, political, and cultural integration into the host community. It has also been recorded that the geographical pattern of proselytization has shifted as Nigeria, India, South Korea, and Brazil have become the new leading missionary sending nations in the world. ${ }^{60}$ Uka adds that " the Latin American Charismatic churches and their African counterparts are contributing to the religious history of the West, especially the United States." He also traced the earliest manifestation of African Pentecostalism in the West to the presence and missionary works of the African, especially Nigerian Independent Churches. ${ }^{61}$

The global level of flow and development of Nigerian Pentecostal churches have also been attributed to the fluidity and complexity of the movement. Their flexibility, variety, and an easy adaptation to social inventions can be traced to their liturgy, organizations, economic practices, and ministerial functions that help them in playing different roles at different places at different times while they still retain continuity and "family likeness." ${ }^{62}$ Meyer sees this fluidity of Nigerian Pentecostalism as a result of the movement's performance rather than a frozen framework backed up by a rigid or fixed religious system. ${ }^{63}$ These insights shed light on how the RCCG in Miami has adjusted to the ethos of the host land in a bid to provide a conducive and productive environment

\footnotetext{
${ }^{60}$ Anderson, Allan. 2004. An Introduction to Pentecostalism. Cambridge: Cambridge University Press, 169.

${ }^{61}$ Ogbu Kalu, African Pentecostalism: An Introduction. (New York: Oxford University Press, 2008): 284- 285.

${ }^{62}$ David Martin, "The Global Expansion of Radical Primitive Christianity," in Kalu's, African Pentecostalism, 21.

${ }^{63}$ Birgit Meyer, "Pentecostalism and Globalization" in Allan Anderson, Michael Bergunder, Andre Droogers, Cornelis Van Der Laan (eds) Studying Global Pentecostalism: Theories and Methods, (Berkeley: University of California Press), 121-122.
} 
for Nigerian migrants. Scholars have attributed many functions to these religious institutions. Olufunke and Okome noted the flow of African Pentecostal churches in the US and described the rate of the flow as a "glorious abandon." 64 They, just like Adogame, pointed out the failure of these African churches in achieving the claim they make. Many African churches have immigrant members only, but a growing number of church leaders claim that their original conceived mission is bringing all people under the umbrella of Christianity through their churches, they note. ${ }^{65}$

Haller, on the other hand, argues that globalization maintains the transnational lives of migrants. For him, the transnationality of Nigerian Churches in the diaspora dispute the hypothesis that immigrants cut off ties to their country after they integrate into the host setting. The African immigrant churches are deep-rooted locally with ties to the land of origin while also keeping up connections through the intra-communal web that joins them with distinctive places across the globe. He goes on to argue that these communities link through religion, politics, economy, friendship, and increasingly by cell phones, particularly the internet (web), which has ended up becoming a key component within the advancement and maintenance of diasporic identity. ${ }^{66}$ Haller noted the interconnectedness of African Pentecostal Christians in the diaspora to the homeland, mostly through the framework of globalization. While this study attests to globalization being one of the processes of the interconnectedness between Africans in diaspora and the homeland, it argues that African Pentecostals churches in the diaspora

\footnotetext{
${ }^{64}$ Okome, Mojúbàolú Olúfúnké. "Emergent African Immigrant Philanthropy in New York City." Krase and Hutchison (eds.) (2004): 179-91.

${ }^{65}$ Adogame, Chitanda and Bateye, African Traditions in the Study of Religion, Diaspora and Gendered Societies, 2013, 100.

${ }^{66}$ Haller, Dieter, "Transcending Locality: The Diaspora Network of Sephardic Jews in the Western Mediterranean,” Anthropological Journal on European Cultures 9/1: 3-31.
} 
provide and present these contexts for Africans to perform, promote and retain their identity, whether through globalization/media or other activities as it offers them context for performance and living a between and betwixt life through the performances. This is exactly one of the themes this study aims at exploring. In studying the roles that Nigerian Pentecostal Churches in the United States play in providing the context for performance and simultaneity, we will see how the flexible and dynamic nature of the church prepares the necessary groundwork. 


\section{CHAPTER 4}

\section{THE REDEEMED CHRISTIAN CHURCH OF GOD IN NIGERIA}

The purpose of this chapter is to introduce readers to the Redeemed Christian Church of God in Nigeria, whose Miami extension is the focus of this thesis. I offer a descriptive account of the Church's origins, historical evolution, and ritual culture in Nigeria. This will give us the necessary background information we need to determine the heritage as well as the creative innovations the church's key agents and community in Miami had to make to shape it to their emerging needs as a migrant group.

The first Redeemed Christian Church of God was established in 1952 in Nigeria by the founder Reverend Josiah Akindayomi, who converted to Christianity from a portion of Yoruba Traditional religion known as Ogun worship. RCCG occupies an important niche in the history and development of Pentecostalism in Africa. It was among the first Charismatic/Pentecostal religious groups in Africa.

According to the church's tradition, God revealed the name, 'The Redeemed Christian Church to Pa Josiah Akindayomi, the founder in a dream. In this dream, God instructed Akindayomi, who was not literate in the English language, to memorize the English words "The Redeemed Christian Church.” A member, who was more proficient in English, wrote the name down when Akindayomi narrated the dream to him. ${ }^{67}$ Ukah notes that the history of the prophecy could not be ascertained, as there was no evidence of where and when it happened, yet, the narrative underlines the establishment and

\footnotetext{
${ }^{67}$ Adogame, Afe. "Contesting the Ambivalences of Modernity in a Global Context: The Redeemed Christian Church of God, North America." Studies in World Christianity 10.1 (2004): 25-48
} 
divine origin of RCCG and the covenant God has with Akindayomi. ${ }^{68}$ The community makes much of the fact that an illiterate in English could memorize the English words uttered in the revelation and interprets the incident as the miracle that inaugurated the Church. The RCCG magazine published during the 50th-anniversary notes accordingly:

It is curious that God did not reveal this name to the prophet in his native Yoruba language, which he would have been able to understand easily. Instead, He chose to communicate with an uneducated man in English so that no one would question the originality and authenticity of the name or even doubt the truthfulness of the vision. ${ }^{69}$

Akinyele observes that in African Pentecostalism, a prophet is revealed by his special endowment made public through such spiritual activities as healing, seeing visions or the power of dreams and spirit-possession. The use of these gifts usually leads to followers imputing charismatic qualities to the leader. ${ }^{70}$ This was precisely the trajectory of Akindayomi's career as a prophet followed. Adekola describes how Akindayomi worked earnestly to define his religious and prophetic portfolio. He prayed

${ }^{68}$ Ukah, Asonzeh Franklin-Kennedy. The Redeemed Christian Church of God (RCCG), Nigeria. Local Identities and Global Processes in African Pentecostalism. Diss. 2003, 72.

${ }^{69}$ Ukah, Asonzeh Franklin-Kennedy. The Redeemed Christian Church of God (RCCG), Nigeria. Local Identities and Global Processes in African Pentecostalism. Diss. 2003, 75.

${ }^{69}$ Omoyajowo, J. Akinyele. 1982. Cherubim and Seraphim: the history of an African independent church, (New York: NOK Publishers International, 1982), 22.

${ }^{69}$ Adekola, Moses Akinwumi. The Redeemed Christian Church of God: A study of an Indigenous Pentecostal Church in Nigeria. Diss. PhD Thesis, Department of Religious Studies, Obafemi Awolowo University, Ile-Ife, 1989, 57. 
for people and performed "miracles of healing, deliverance from evil powers. ${ }^{71}$ Akindayomi soon established his independent identity as a prophet, that is, one who spoke the mind of God, a healer of diseases, a deliverer of the afflicted from satanic oppression, and a seer of visions. ${ }^{72}$

Adeboye Enoch Adejare, who took over the Church after Akindayomi, rejuvenated it. Typical of newly formed religious movements, the RCCG started as an egalitarian movement of twelve core members. Their symbols of unity were their shared belief in spiritual agency and the divine leadership of the founder. ${ }^{73}$ However, over the years as the church expanded, necessitating some restructuring. Adeboye was instrumental in its restructuring and eventual bureaucratization.

According to the RCCG's tradition, the Holy Spirit is the leader and head of the church. The human leaders or general overseer are agents of the Holy Spirit and therefore vested with sacred authority. General Overseer's words are law because they emanate from God. There are other offices-- the Assistant General Overseer, and a Governing Council which consists of high-ranking pastors and regional coordinators. The local coordinators supervise the global branches of the institution; the United Kingdom, the Middle East/South Asia, North America, South America, Northern America, Europe,

${ }^{71}$ Adekola, Moses Akinwumi. The Redeemed Christian Church of God: A study of an Indigenous Pentecostal Church in Nigeria. Diss. PhD Thesis, Department of Religious Studies, Obafemi Awolowo University, Ile-Ife, 1989, 57.

72 Adekola, Moses Akinwumi. The Redeemed Christian Church of God: A study of an Indigenous Pentecostal Church in Nigeria. Diss. PhD Thesis, Department of Religious Studies, Obafemi Awolowo University, Ile-Ife, 1989, 64.

${ }^{73}$ Asonzeh Uka. World Religion and Spirituality: The Redeemed Christian Church of God. 2014 https://wrldrels.org/2016/10/08/redeemed-christian-church-of-god/. Accessed Jan 22, 2020. 
and Southern Africa. However, the financial, administrative, and spiritual power concentrate in the office of the General Overseer. He is vested with the power to make all decisions on matters affecting the community.

The RCCG temple in Lagos referred to as "Redemption Camp," is the global headquarters. The headquarters accommodates more than a million worshippers during the Church's its monthly Friday night evening devotional session called "The Holy Ghost Night." Anderson has noted in his work on the RCCG that as of 2010, it had over two million adherents globally. ${ }^{74}$

The RCCG's branches are referred to as areas. Each area is divided into zones and each zone is sub-divided into several parishes. Coordinators administer the parishes. ${ }^{75}$ RCCG North America comprises the United States, the Caribbean Islands, and Canada and is divided into ten zones. The first RCCG church in the United States was founded in Detroit, Michigan, in 1992. Several parishes have been established in different states such as Texas, Florida, Massachusetts, to mention a few. It has been recorded that RCCG has more than six hundred branches in the United States. In 2018, Adeboye, the General Overseer of RCCG, visited Samford University as a Guest speaker. $^{76}$

\footnotetext{
${ }^{74}$ Anderson, Allan. African reformation: African Initiated Christianity in the 20th century (Africa World Press, 2001), 175, Anderson, Allan. "African Pentecostalism and the ancestor cult: confrontation or compromise." Missionalia: Southern African Journal of Mission Studies 21.1 (1993): 88-94.

75 "The Structure, Administration and Finance of the Redeemed Christian Church of God in North America”, Dallas, Texas; RCCG Heasdquaters, 2003.

${ }^{76}$ Bill Nunnelley, "Adeboye Head of Worldwide RCCG Church to Speak at Samford University" Oct.23, 2014
} 
There is a sense in which the RCCG can be said to combine elements of Independent African Churches (AICs) or Spirit/Spiritual churches and African Pentecostalism. The African Independent churches can be said to represent the leading edge in the contextualization of Christianity in Africa. ${ }^{77}$ As by-products of the encounter of indigenous African Religions with missionary established Christian forms, the liturgy of Independent African Churches (AICs) emphasizes spiritual gifts--the sense that each person is endowed innately with a unique supra-mundane ability. It is incumbent on all worshippers to identify their gifts through their engagement in prolonged spiritual disciplines. They must then use these gifts to enhance the quality of their lives and the lives of other members of the community.

The oldest African Independent churches in Nigeria include the Cherubim and Seraphim Church (also called Aladura) and the Christ Apostolic Church, to mention a few. A group of scholars argue that AICs and African Pentecostalism resemble each other because they are results of Africans trying to break free from the clutches of colonialism and Westernization. ${ }^{78} \mathrm{AICs}$ represent the earliest expressions of this resistance. African Pentecostal churches emerged later as radical expressions of cultural resistance, enabling African blacks to mitigate the suffering capitalism, colonialism, and apartheid imposed on them. ${ }^{79}$ Although the AICs seldom self-identify as "Pentecostals" or Charismatics,' it is the opinion of some scholars that they are both

\footnotetext{
${ }^{77}$ Bill Nunnelley, "Adeboye Head of Worldeide RCCG Church to Speak at Samford University" Oct 23, 2014

${ }^{78}$ Minchakpu, Obed. "All Levels of Society in Nigeria Touched by Charismatic Revival." The Blessings Page: A Periodic Magazine of Spiritual Renewal (2000), 1-2.

${ }^{79}$ Kgatle, Mookgo Solomon. "African Pentecostalism: The Christianity of Elias Letwaba from early years until his death in 1959." Scriptura: Journal for Contextual Hermeneutics in Southern Africa 116.1 (2017): 4
} 
African expressions of Pentecostalism because of their shared characteristics, theology, and history. ${ }^{80}$ Reverend Josiah Akindayomi, the founder of the RCCG, was a Prophet in the Aladura Church, an AIC before he established the RCCG. Perhaps this explains why the RCCG still has a strong AIC flavor, although it self-identifies as a Pentecostal Church.

\section{The Discourse}

As an African Pentecostal form, the RCCG does not reject the spiritual forces acknowledged in traditional African religions. It rather redefines them, engages in the struggle against them, and takes the Bible very seriously as the fundamental spiritual weapon worshippers must enlist in this struggle. ${ }^{81}$ With its theology of the Holy Spirit as an agent active in the lives of worshippers, the RCCG offers its followers a dynamic Christianity that meets African needs. This is a factor explaining its unique appeal in Nigeria and its diasporic extensions.

The RCCG has emerged as one of the most complex Pentecostal organizations in Nigeria, Africa, and even beyond. As a Pentecostal tradition, Christian forms of worship and patterns of church organization seem to define the overall framework of worship in RCCG. The church believes in God as a father figure and the Creator of the universe. God assumes the guise of Jesus, his Son, and performs the role of the redeemer of humanity. God also manifests as the Holy Spirit, which is the purifier of humans. The Church emphasizes miracles of redemption, the power of the Holy Spirit and His ability

\footnotetext{
${ }^{80}$ Anderson, Allan. An Introduction to Pentecostalism (Cambridge Up, 2014), 115.

${ }^{81}$ Kgatle, Mookgo Solomon. "African Pentecostalism: The Christianity of Elias Letwaba from early years until his death in 1959." Scriptura: Journal for Contextual Hermeneutics in Southern Africa 116.1 (2017): 1-9.
} 
to work wonders, healing without medicines, and material wealth as the manifestation of divine succor. There is a strong belief in three types of baptism; water baptism, baptism by the Trinity, and baptism by the Holy Spirit. The church has a strong prophetic tradition that pays respectful attention to the power of prayers, repentance, and restitution. Its doctrines also include eschatological and apocalyptic messages such as the second coming of Christ, the millennial reign of Christ as King, a final judgment, new heaven, and a new earth. The devil, Satan, and his agents, witches, demons, and many other malignant and evil spirits are real in RCCG, and the Holy Spirit alone has the power to subdue these spirits. ${ }^{82}$ The Bible is taken as infallible and inspired by the Holy Spirit. The Bible is also the constitution of the Church and the cannon of faith. RCCG's doctrines are stipulated in the church's "Vision /Mission Statement." The Statements are;

- To make heaven.

- To take as many people as possible with us.

- To have a member of the RCCG in every family of all nations.

- To accomplish No1, holiness will be our lifestyle.

- To accomplish Nos 2 and 3 above, we will plant churches within five minutes walking distance in every city and town of developing countries and within five minutes driving distance in every city and town in developed countries.

- We will pursue these objectives until every nation in the World is reached. ${ }^{83}$

\footnotetext{
${ }^{82}$ Adeboye, Olufunke. "Arrowhead of Nigerian Pentecostalism: The Redeemed Christian Church of God, 1952-2005.” Pneuma 29.1 (2007): 24-58.

${ }^{83}$ Trost, Theodore L. The African Diaspora and the Study of Religion, (Basingstoke: Palgrave Macmillan, 2007), 23.
} 
The list above ends with the church's Motto, “Jesus Christ the Same Yesterday, Today and Forever." As we will find out in the next chapter, the quest to accomplish the second, third, and fifth goals contributed to the establishment of the RCCG in Miami, Florida. In other words, the RCCG has a global expansionist agenda in keeping with its objectives as stipulated in the Mission Statement.

Although Christianity might be said to provide the foundation for the RCCG, like many African Pentecostal Churches, it has developed its unique answers to a variety of questions defined by the specific social-cultural setting of the worshipping community in Nigeria. This lends the RCCG to the strong influence of indigenous Nigerian religions. Notably, the Yoruba religion, of which the founder was a staunch adherent prior to his conversion, has left indelible imprints on the habitus of this Pentecostal form. I will identify some of the uniquely indigenous Nigerian religious elements that define the RCCG's religious habitus. The spontaneous congregational sung glorification of God or Jesus that is typical of RCCG's devotional sessions, the democratic participation of all worshippers during devotion, the strong belief that prayer and other rituals are spiritual technologies that channel spiritual power towards the production of material well-being for worshippers, the focus on the pursuit of wealth and health in the here and now, rather than the hereafter, are elements borrowed from indigenous Nigerian traditions.

Additionally, there is a belief in the presence of a plethora of supernatural agents operating in the physical world and thwarting the efforts of humans to succeed in their endeavors. These agents include witches, angry ghosts and ancestors, and sorcerers, who are purveyors of evil in Yoruba religion but have been grafted onto Christian theological notions of evil as the agents of Satan. Building on Yoruba religious beliefs, RGCC's 
discourse on evil is that the universe or earth is a battle zone. Agents of evil are continually battling with God, and his agents on earth, and human beings are caught up in the crossfire. The only way out of this predicament is for human beings to form alliances with God and his agents in the battle against the agents of evil. This indigenous Yoruba religious idea is an important basis of the RGCC's practice of prayer warriorship. A practice that has now spread to all Pentecostal movements in Africa. Prayer warriors are groups within RGCC churches, whose preoccupation is praying for the Church. They are viewed as agents of superior magico religious power because of their constant praying, and as spiritual warriors protecting the entire worshipping community.

These are only a few of the elements that define RGCC as a distinct Nigerian Pentecostal form. In Nigeria, worshippers do not make much of the presence of these African elements in their Pentecostal tradition. Many are not even aware these elements are of Yoruba or other indigenous religious provenances. Worshippers view them as simply Pentecostal notions and practices. While Pentecostal pastors in Nigeria are undoubtedly aware their traditions are built on indigenous Nigerian religious beliefs and practices, they tend to play down these indigenous influences. In what we can describe as a paradox, many Pentecostal leaders publicly delegitimize African religious beliefs and practices, the very foundation on which they build their careers. In the next chapter, we will see how these indigenous Nigerian religious elements assume new and important significances in the Nigerian diaspora in America as signs of a distinct African form of Christianity. We will see that one reason Nigerian migrant worshippers are drawn to the RGCC in Miami is the indigenous Nigerian flavor of its religiosity. The chapter will demonstrate how Nigerian migrant worshippers in Miami seek to participate in the 
RGCC's religious practices that offer them opportunities to perform their ethnic identities in practical and symbolic ways. An element that the home church shows little respect for will become the key foundation of its diasporic extension in Miami.

\section{CHAPTER 5}

\section{THE STORY OF THE REDEEMED CHRISTIAN CHURCH OF GOD IN MIAMI}

The Redeemed Christian Church of God does not have comprehensive written records either of the events leading to the origin of the Miami portion or about the Nigerian migrant community's history in Miami over the years. The absence of detailed written historical sources has made the task of reconstructing the history of this Church and its community in Miami difficult. However, in that, the community is only a generation old, I was fortunate in being able to rely on oral accounts of historical events from the people directly concerned. These accounts often sounded inconsistent, however, and I was often annoyed that people's memories seemed to be unclear about what I would consider important dates, names, and places.

Notwithstanding the difficulties, I was able to piece together a reasonably complete picture and was able to check and recheck historical details as I understood them with the leaders, priests, and other founding members of the Church. One reason for telling members of the community how I understood their account was to allow them to critique my account of their history and to control any reconstruction of events that I might make. This way, I ensured that the reconstruction was largely shaped by their voices, even though some of the interpretations had to be mine. 
The aim of this chapter is to trace the events that culminated in the origins of the RCCG in Miami. We will see how the home Church's desire to expand globally becomes enmeshed with the felt needs of Nigerian migrants in Miami to integrate as a unit in the face of their social and religious conditions as a migrant group. The result of this process was the formation of the RGCC worshipping community in Miami. I will describe the worshipping community and then go on to offer an analytical account of how the community came to be established in North Miami.

The Redeemed Christian Church of God is located at 14101 NW 6th Avenue, Miami, Florida. It is not immediately evident that the building is a church because the RCCG parish in Miami does not operate in a cathedral. By this, I mean, nothing tells a passerby of the existence of the church until the person comes close enough to take notice of the poster on the gate. On this poster is the logo bearing the name of the church. Furthermore, only upon entering the building will one realize from the pictures of Jesus hanging on the walls, the drums, the piano, and the arrangement of the seats that he or she was in a Pentecostal Church.

The RCCG has a population of about two hundred. Of the two hundred members, about ninety are women, sixty are men, and fifty are children. The majority of the members are between the ages of twenty-five and seventy. There is the active participation of the youths who are mostly children or relatives of adult members, but who often sit together and use the opportunity for important social contact with their peers during worship. Some of the children are only a few months old. The majority of worshippers belong predominantly to the working class. Most of the male worshippers work as factory hands, clerical officers, technicians, accounting clerks, janitors, and cab drivers. A few of them are self - employed and own convenience stores in their 
communities in South Florida. Some members are students of various South Floridian Universities. While a variety of African ethnicities (such as Ghanaians, African Americans, and Caribbean,) are represented in the membership, the majority are Nigerians, especially the Yoruba. The Igbo, Edo, Urhobo, Isoko from Nigeria are also represented. Often the members from the other African ethnicities attend the church as visitors during special occasions, such as Christmas and Easter.

Few of the worshippers are permanent residents or citizens in the USA. A significant number of them are immigrants with non-immigrant status. Some are students on F1 visas and tourists with a permit that allows them a temporary stay. The church's compound is large and has a large children's playground, the lobby, a space for the children's ministry, and the auditorium. The church auditorium can accommodate up to 400 hundred individuals. A glance at the auditorium's wall reveals the Nigerian images that welcome the worshipper to a Nigerian world of Pentecostalism.

\section{Organization of the Church}

The church is organized into different groups or ministries as they are referred to, and each department has exclusive responsibility, which is performed differently but functions simultaneously to ensure the smooth running of the church. The groups are the men fellowship, the good women fellowship, youth or young adult group, children's ministry, media ministry, house fellowship, usher's ministry, community outreach, and the prayer ministry. The men and women's' ministry work together to enhance the general well-being of the worshipping community. A deacon of the church heads the men's fellowship. Members of this group meet regularly to inspire and encourage each other, to discuss the "word of God" and issues concerning men as the head of families, 
for prayers, and other social activities. They fellowship with each other and work on their self-improvement, striving to become better leaders, more loving spouses, caring fathers, more energetic providers, better-equipped gatekeepers, and honorable men. ${ }^{84}$ The good women fellowship consists of mothers in the worshipping community. They extend their domestic motherly roles into the worshipping community, socializing the youth in ways that lead to healthy personal growth and enriched life. Mainly, they are concerned with the empowerment of women, primarily mothers, in spiritual and practical ways. They meet to pray for their spouses, children, their home nations as well as their host nation, the United States of America. They are also responsible for organizing social events that the Church hosts.

The ushers' group is involved in the vital role of maintaining order in the church. The group directs and guides traffic before and after Church activities, help visitors, ensure the safety of the premise, and generally ensure the smooth flow of church activities. The choir group or praise team, as they are sometimes referred to, is in charge of the music during worship activities. It is their responsibility to ensure that the Holy Spirit of God moves members through their Spirit-filled ministrations of songs and praises. In RCCG, prayer can never be overestimated as it is a common belief that everything is possible through prayer. The prayer warriors are groups of members that have committed themselves to praying on behalf of the worshipping community.

Throughout the week, the members meet to pray about different issues concerning the church in Miami and internationally. They also attend to special prayer

\footnotetext{
${ }^{84}$ RCCG Open Door Parish https://rccgodlexington.org/ministries/ . Accessed 01/30 2.30 am.
} 
requests from members of the church. ${ }^{85}$ The media and technology group controls the media technology the church uses.

The youth or young adult group consists of unmarried members. This group brings young men and women together in fellowship. One of its key responsibilities is carrying out the church's public outreach initiatives, such as evangelism and the organization of conferences. The children's department is the group that takes care of the children's needs as determined by the church leaders. The most important task of this group is the early religious education of children.

The church is run under the supervision of the Parish Pastor, Pastor Onyinaya Ugochukwu, and his wife, Mrs. Evelyn Onyinaya. There are also a few deacons and deaconesses of the church who perform administrative roles. The leadership and executive authority of the church are, however, answerable to the regional coordinator in the United States who is in turn accountable to Reverend Adeboye, the General Overseer of the Redeemed Christian Church of God in Nigeria.

\section{The Origins Story}

The church started in 1998 as a gathering of Nigerian families in Miami that held weekly devotional meetings in a member's home. Many of these families were members of the RCCG in Nigeria before their migration to the United States. In narrating the story of their beginning, respondents would often start into harrowing descriptions of how they had to move from one church to the other in Miami in search of a community that met their needs. What many said was that they were looking for a church whose practices

\footnotetext{
${ }^{85}$ RCCG Victory Parish MIami https://www.rccgvictory.org/ministries/ Accessed 01/31, 2020.
} 
were familiar in the sense that they were similar to the devotional culture they had left behind in Nigeria.

The group increased in numbers as news of members' "breakthroughs" attracted other migrants, some of whom came from other African countries such as Ghana. The breakthroughs included the healing of members' illnesses, success with the acquisition of visa and resident permits, gaining employment, and success with business contracts in Miami.

According to Ugo (an engineer), the various breakthroughs and dramatic growth in the number of the group's members were signs that "the time had come to find a permanent space to serve the Lord and the broader African migrants, and even the host American community. With time the growing population began to rent a conference room in a hotel for its meetings. When the cost of renting this space started to rise, the community started to look for a permanent space. This was when some members contacted the RGCC headquarters in Nigeria, seeking permission to initiate an oversea branch in Miami. The home church quickly seized this initiative seeing it as an opportunity to fulfill the mandate to spread the influence of the church beyond Nigeria. The pastor in charge of the Miami parish described this move as the fulfillment of a covenant, a covenant that the leader of the church supposedly had with God for the establishment and sustenance of the Church:

God, like He did with Abraham, established a covenant with Rev. J. O. Akindayomi to the effect that He would meet the needs if [sic, of] the church in an awesome way, if only members of the church would serve him faithfully and be obedient to his Word. It is upon this covenant that the Redeemed Christian Church of God was built. ${ }^{86}$

\footnotetext{
${ }^{86} \mathrm{RCCG}$ at 50, p.16. There is a verbatim reproduction of this text in Redemption Light, vol. 7, no. 7 , August 2002, 7.
} 
He continued after a moment of reflection:

God has placed the redemption and liberation of the whole world in our hands. This is a covenant between no two mortals but between His Blessed Memory and Faithful, Pa Akindayomi, and God. We are messengers, and this church is the vanguard. We are the vessels that will fulfill this covenant of establishing God's kingdom on earth. ${ }^{87}$

\section{Making Ethnographic Sense of the Origins Story}

A point that is clear from the narrative on the origins of the worshipping group that became the RGCC in Miami is that the need for space by a community of worshippers to address spiritual questions arising from their migrant situation pushed the founders to create a group. Another point the story demonstrates is that the Nigerian migrants' desire was for a familiar religiosity that would speak to their post-migration concerns. What increased the fortunes of the group was the intervention of the home church. This transformed the prayer group into a church, the RGCC in North Miami. Here, we can see that the desire of the migrant community to have a place to perform worship was as equally important as the need of the home church to proselytize overseas.

Adogame argues that one characteristic of religion in the United States is the ethnic aspect of denominationalism. Religious institutions are established along ethnic lines, leading to the common description of "ethnic-based churches." 88 This research attested to this as the RCCG in Miami has Nigerians making up ninety-nine percent of the congregation. Nevertheless, Adogame also notes that African immigrant religious institutions move to create connections between immigrant communities in the host land

\footnotetext{
${ }^{87}$ Reverend Ugochukwu, "Interview," December 2010, at the office of Redeemed Christian Church of God Miami, Florida.

${ }^{88}$ Trost, T., (ed). The African Diaspora and the Study of Religion (Palgrave Macmillan, 2007), 28.
} 
and religious communities in the homeland. ${ }^{89}$ Again the history of the RCCG in North Miami reflects this trajectory. Equally important for our understanding of this story in the ethos of Miami, the context of migration. This ethos augurs well for the establishment of ethnic-specific churches. The 2016 population record that Miami is the 6th most densely populated city in the United States. More important, Miami is a meeting place of different ethnicities. These ethnicities seek ways to form an identity in the diaspora. Religion offers for these migrants the much-needed symbol of integration. My fieldwork found out that within the vicinity of the RCCG, there are few other African ethnic-based Pentecostal churches. There are Ghanaian, Liberian, and African American dominated churches too.

The history of the Redeemed Christian Church of God in North Miami shows that its establishment cannot only be explained by the home Church's vision to establish oversea extensions in places such as the United States and the Caribbean. The initiative of creating a church came from the Nigerian migrant community in Miami. As a migrant group, the community faced challenges associated with its settlement and saw the need to engage these issues spiritually. But what it sought to have mostly was a spirituality member would be familiar with in a cultural sense — one that was heavily inflected with a strong indigenous Nigerian flavor in terms of the discourse and practices. The dissatisfaction respondents said they felt being in Churches that were not Nigerian points to this fact. But this also means that the religiosity the community was seeking should be one that would also function as a marker of their cultural identifies as Nigerians and

\footnotetext{
${ }^{89}$ Trost, T., (ed). The African Diaspora and the Study of Religion (Palgrave Macmillan, 2007), 26.
} 
therefore a symbol of their oneness. Therefore, the community reached back to the homeland requesting help from the RGCC, whose religious culture many were already familiar with. The quest of a home-based church to expand globally, therefore, coincides with the desire of the Nigerian migrant community to have a religious space they could call their own, with beliefs and practices they were familiar with and where they can perform religious in ways, they are accustomed with. The end product of these initiatives was the creation of the RGCC in North Miami. 


\section{CHAPTER 6}

\section{THE REDEEMED CHRISTIAN CHURCH OF GOD AS A PERFORMING GROUND}

\section{Introduction}

Olupona has described how African ethnic identities in the United States are connected to migrants creating quasi-communities of their homelands in the host land in connection to and remembrance of their homelands. ${ }^{90}$ He notes how the migrants' creation is accomplished by giving importance to the cultural values of the homeland where community members emphasize speaking and hearing their languages, having the opportunity to enjoy special food delicacies, instituting programs and events that include ethnic markers such as clothing styles, flags, and reference to cultural values or beliefs. ${ }^{91}$

The discussion that follows in this chapter bolsters Olupona's observations in that it will show how the Nigerian Pentecostal tradition of RCCG in Miami culturally, socially, and religiously provides a context for Nigerians to perform their cultural values and practices and to keep the memories of the homeland constantly on their minds.

Though Pentecostal churches modify their traditions and practices to conform to their community contexts, Pentecostal practices in Nigeria usually fall within a structure. The unique Nigerian traditions and characteristics found in Nigerian Pentecostalism are, for

\footnotetext{
90 Olupona in Asamoah-Gyadu, J. Kwabena. "“From Prophetism to Pentecostalism": Religious Innovation in Africa and African Religious Scholarship." African Traditions in the Study of Religion in Africa: Emerging Trends, Indigenous Spirituality and the Interface with Other World Religions (2012): 161.

91 Olupona in Asamoah-Gyadu, J. Kwabena. "“From Prophetism to Pentecostalism": Religious Innovation in Africa and African Religious Scholarship." African Traditions in the Study of Religion in Africa: Emerging Trends, Indigenous Spirituality and the Interface with Other World Religions (2012): 161.
} 
instance, music and songs, often sung in indigenous Nigerian dialects, usually Igbo and Yoruba dialects, and less often Ikot dialects. There is the regular interruption of events with songs, spontaneous singing, and dancing accompanied by clapping of hands. Also, devotional and prayer sessions are extremely prolonged to let the Holy Spirit in for anointing and deliverance. Teachings on demons (emi okukan) ${ }^{92}$, witches (aje, ajommuo $)^{93}$ wizards (oso), satan (esu, ekwensu) $)^{94}$, ancestral curses (egun idile) ${ }^{95}$ which could be assuaged through the infilling of the Holy Spirit and fervent prayers dominate the discourse. This gives Nigerian Pentecostalism a typical frame of reference even if there are slight contextual diversities.

I argue in this chapter that although now living in America, the feeling of being Nigerian is of central importance for Nigerian migrants. Through its Nigeria-specific Pentecostal culture, the RGCC in Miami offers a context for the production of this feeling and the participation of its members in it. I offer an account of the rituals and traditions that exemplify this specific Nigerian Pentecostal culture that the RCCG offers its worshippers, demonstrating how they provide opportunities for them to show how Nigerian they are in religious, social and cultural ways. I also argue that not only do the indigenous Nigerian religious practices and worldviews which define Nigerian Pentecostalism and on which the RCCG in Miami is founded furnish the cultural and social setting which allows members to feel and demonstrate their Nigerian identities, the church's activities also foster among its Nigerian members a strong sense of being

\footnotetext{
${ }^{92}$ A Yoruba (A Tribe's Nigerian) name for Satan or demons.

${ }^{93}$ Igbo and Yoruba names for witches (both Nigerian languages)

${ }^{94}$ Name for Satan in Igbo and Yoruba

${ }^{95}$ Adogame, Afe. "Engaging the rhetoric of spiritual warfare: The public face of Aladura in diaspora." Journal of Religion in Africa 34.4 (2004): 493-522.
} 
connected to Nigeria in direct and symbolic ways. The discussion will show how this feeling of being connected to the homeland is essential to the Nigerian migrant worshippers in Miami. We will also see that for the other African ethnicities such as African Americans in the church, what is important is not necessarily the Nigerian cultural flavor of the church but the opportunity to build on the African flavor of the tradition's ritual culture to demonstrate a sense of African-ness they wish to reclaim and participate in.

In the discussion that follows, I will not cover every ritual practice of the RCCG in North Miami. I will pay more attention to the rituals and other instituted practices that offer the migrant worshippers the opportunity to perform their Nigerian ethnicities.

\section{The Prayer Warrior Tradition}

On December 12th, 2019, I arrived at the premise of the RCCG at 9:30 am. As I opened the door to the auditorium door, a young lady wearing a suit with an usher's tag stretched out her hands to me. She muttered, "Welcome to a place of victory." After we shook hands, she handed me a Sunday school manual. She also ushered me to my seat. At this time, there were only a few people in the auditorium. As I sat down, I could hear the songs and prayers going on in the auditorium's lobby. I heard a voice admonishing the group to "pray for the Holy Spirit to have His way today." This came from the leader of the 'prayer warriors' of the church. He was praying to the Holy Spirit to quicken people's

steps to the church that Sunday. Describing the heightened spirituality typical of Nigerian Pentecostalism, Ayuk's assertion sheds some light on the rationale behind the prayer warrior tradition: 
By nature, they are spiritual. It is not like other humans are not spiritual, but it is just that they are more attuned to the spiritual than the physical. A Nigerian by nature, looks at life from a spiritual dimension rather than from a rational point of view. ${ }^{96}$

Building on the Yoruba belief that the universe is a war zone and human beings are caught in the "crossfire" when supernatural agents of harm engage in spiritual battles with benevolent supernatural forces the RGCC instituted the spiritual warrior practice as a way of empowering worshippers spiritually so that they can offer spiritual protection for themselves and the rest of the worshipping community.

At precisely $10 \mathrm{am}$, the spiritual warriors all came into the auditorium and divided themselves into four groups. After a very prolonged session of prayers led by the spiritual warriors, there was a brief interlude. This was followed by the community's Sunday school session. The spiritual warrior tradition is a typical example of a practice that enables worshippers of the RGCC to perform spiritual protection themselves rather than remain passive and expect the succor of divine agents to gracefully flow into their lives. The practice endows lay worshippers with agency and instills in them feelings of personal spiritual empowerment. The sense is that spiritual protection does not only come from God or Jesus but also from one's engagement in spiritual disciplines or exercises such as meditation, fasting, and persistent prayer. Personal spiritual fortification is a common indigenous Nigerian religious practice. Individuals consult with ritual specialists who fortify them spiritually by using a number of cultural techniques - following specific ritual formulae, having powdery substances poured into incisions made on the body, wearing power-charged necklaces prepared by ritual

\footnotetext{
${ }^{96}$ Ayuk, Ayuk Ausaji. "The Pentecostal Transformation of Nigerian Church Life." Asian Journal of Pentecostal Studies 5.2 (2002): 189-204.
} 
specialists, etc. The prayer warrior tradition is, therefore, in keeping with a Nigerian cultural practice, and participating in this ritual makes worshippers feel at home in a religious and cultural sense, although the context is a Pentecostal one.

\section{The Sunday Service}

Overseas African Pentecostal churches are noted to follow the patterns of worship of the mother churches in the homeland. These include the coordinated expression of worship in dancing, singing, giving of testimonies, speaking in tongues, preaching, simultaneous prayers, and so on. In RCCG Miami, Nigerian languages (mostly Igbo and Yoruba) are used alongside the English Language during worship. In this connection, Harvey Cox notes: "The great strength of Pentecostal worship is in its power to combine, the aptitude for adopting the language, the cultural artifacts, the music...of the settings in which it lives." 97 The RCCG in Miami's Sunday service is a purely autogenous Nigerian affair that offers worshippers the opportunity to engage in a number of cultural performances.

The Sunday service starts immediately at the end of the Sunday school. The choristers mount the stage in their colorful dresses and encourage the congregation to "do something for Jesus." ${ }^{98}$ At this, the congregation bursts into a state of frenzy and, performing different actions, some making unusual noises, some cheering "Alleluia, Alleluia," others clapping their hands, and others jumping. At the corner of the stage are a set of African drums, a collection of bands, a piano, and other musical instruments.

\footnotetext{
${ }_{97}$ Cox, Harvey. Fire From Hheaven: The Rise of Pentecostal Spirituality and the Reshaping of Religion in the 21st Century (Da Capo Press, 2009), 259.

98 The term used to cheer and motivate people to praise God.
} 
The leader of the choir steps in front of her group, microphone in hand and reminds the congregation that it is time to praise God. She begins with the RCCG's anthem:

J We are Redeemers, united in love

Jesus is for us.........we shall conquer.

We are together, united in love

Jesus is for us......... we shall conquer

We are victorious, united in love

Jesus is for us......... we shall conquer. ${ }^{99}$

A resounding cheer greets the completion of the anthem marking the beginning of the devotional session. The lead singers of the chorister start into a praise song as the congregation joins. Some worshippers dance while others cheer. There are different kinds of dances and sounds. Many of the dances wear traditional Nigerian dance forms of different ethnic provenances, with the Yoruba dance forms dominating. Ayuk's characterization of a typical Nigerian Pentecostal devotional session vividly captures the mood. He notes, "Nigerians are very active people, they do not like anything solemn. Moreover, they like to swing and move and swing. That is the nature of a Nigerian and invariably the nature of Pentecostalism." ${ }^{100}$ For them, RCCG is a place where they worship God in the Nigerian way.

\footnotetext{
${ }^{99}$ RCCG's Anthem

${ }^{100}$ Ayuk, Ayuk Ausaji. "The Pentecostal transformation of Nigerian church life." Asian Journal of Pentecostal Studies 5.2 (2002): 189-204.
} 
The singing and dancing last about twenty minutes. As the session ends, a lady walks to the pulpit and announces the various activities of the week. The activities include digging deep/faith clinic, midweek/bible study, a youth fellowship meeting, etc. She also makes a call for volunteers in the children's department. The pastor reiterates some key points of her announcement when he takes over the microphone. He also admonishes members to serve God with their whole heart through active participation in devotion. After the announcements, the choir leads a different ritual - "worship and adoration." This is the portion of devotion during which the tempo of the songs slows down and the singing is accompanied by congregational speaking in tongues. Some worshippers weep as they speak in tongues. What struck me was that the songs were in Nigerian dialects. The first one was in Igbo (a Nigerian language);

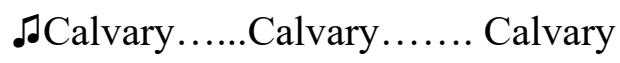

Agaghi m echefu calvary. (Igbo language)

This can be interpreted as "I will never forget Calvary," The goal of this session was to "set people in the proper mood to receive the word of God."101 Worshippers also sang songs in Yoruba and English. The pastor moved to the altar and took over the singing from the lead chorister. He started tongues speaking session, followed by some utterances in English:

Tell God that you have come to His presence today... Tell him about that problem that you have.... Tell Him that you know that he had taken away your pain and sorrow when he died on the cross. You can take any position of your choice right now and tell God whatever troubles you. The Holy Spirit is here, moving in this place and

${ }^{101}$ Personal interview with Rev. Ugochukwu in Jan 2020 at his office. 
waiting for you to approach God with your faith today. There is nothing impossible, for our God to do. ${ }^{102}$

The atmosphere became more frenzied as worshippers quickened the paces of their movements in whatever actions they were taking. Then the pastor started into a song:

JOdighi ihe Chinekem apughi imeeeeee

Odighi ihe Onyenwem apughi imeeeee

I ma n'odighi ihe Chineke $m$ apughi imeeeee

Odighi ihe Onyem n'efe apughi imeeeeeee (Igbo language)

We can interpret these words in English as "There is nothing that God cannot do. There is nothing impossible for our Lord to do." At the end of the 5th stanza of the song, the pastor cheered, "if you believe this song, do something for Jesuuuuus!" The congregation cheered in different Nigerian languages and dialects.

The pastor then declared that it was time to share the word of God. He asked the group to sit, and the sermon began. He opened his tablet and asked the listeners to fetch their Bibles. Most of the members read the scriptures from their tablets, laptops, smartphones. The biblical verses appear on television screens mounted on the walls of the auditorium. The pastor began preaching his sermon: "This year 2020 is a year of God's plantation; therefore, I bring the message 'be planted in God's house' to you today" The sermon completes the worship session on Sundays.

Congregational singing, clapping, and dancing are typical of Pentecostal practices. However, from the description above, we see that there is a cultural aspect of this church's worship tradition. The tradition has a distinct Nigerian flavor. The songs

${ }^{102}$ Sunday Sermon on 12 Feb 2020. 
are mostly from the Nigerian Pentecostal tradition, the dance moves are culturally familiar because they originate from Nigerian ethnic groups, and the languages and dialects used are from different Nigerian ethnic groups. The devotional songs are not only commonplace, their lyrics reflect indigenous Yoruba, Igbo, and other Nigerian ethnic worldviews. Worshippers do not only recollect the worship culture they left behind in the homeland, they perform it and collectively participate in the moods generated. The worship tradition brings "home" to North Miami. Within the space and the duration in which they worship, these migrant worshippers are recreating "home," even if only temporarily. This is not only a religious performance-it is primarily cultural -. Religion is only providing space for its performance. Some respondents' views during our interviews reflected their sentiments.

One of my respondents described the worship tradition of the RCCG in North Miami as a "home reminder." He said:

Every day in this country, almost everywhere we go, we speak English. You know we are in Miami and all you hear around you or speak in public is either English or Spanish. The only place we come to and do not have to continue speaking English is here at church. It is always a good feeling to worship God in one's language. The mood change can tell you what being Nigerian in a different land feel like. I sing in Igbo or I sing in Yoruba, and I am happy. I dance the way an Igbo dances or the way a Yoruba dance and it is fulfilling. This is one of the reasons I love this church. ${ }^{103}$

In offering explanations for the use of different languages, including English, the pastor stressed the need "to accommodate every member's ethnic needs." He elaborated:

A few times, we have people who are not Nigerians visiting the church. Singing in the English language helps them understand the meaning of what is being sung. If it was left to most of the Nigerian members, (he giggled), they would prefer that we do the singing in the

${ }^{103}$ Ugochi Onyekwelu. Personal Interview after a Sunday Service in Jan 2020. 
native language always. I have had to explain to them that this church is not only for Nigerians, that is why we go for Evangelism. ${ }^{104}$

A lady, who studies Electrical Engineering at Florida International University, quickly responded, "This is the home family that God has given to me in a foreign land," ${ }^{105}$ when I asked her how she felt about worshipping in the church. When I probed further, she started into a lengthy narrative:

When I arrived in Miami, I was like a lost person. The first week here was so unbearable that I almost went back to Nigeria because of the loneliness and homesickness that I felt. At school, during my second week, I ran into this Nigerian, and he asked me if I knew any church around. On learning that I knew none, he introduced me to this church. I did not have a car, but he assured me that the church will arrange for transport to take me from anywhere I lived. I gave him my address, which he provided to the driver. The next Sunday, the driver arrived with the church van and brought me to this church. The moment I got there I knew I was home. The way I was welcomed by everybody when they found out that I just arrived from Nigeria thrilled me. The Mummy of the church adopted me as her child, my sisters in the church introduced me to places I could purchase Nigerian and African things. My spiritual life did not diminish a bit. That is the best part. Though I was not a member of "Redeem" in Nigeria, I did not feel lost or homesick. Every practice here is very Nigerian. So, this church serves as my physical home and also as my spiritual home even though I am away from home.

She continued after a moment of reflection:

My life became a lot easier. The girls here make my Nigerian hair weaves for free. This church has contributed a lot to my settling down here because I do not feel I have left Nigeria. Not only do we sing and dance the way we do back home, we communicate with each other in our dialects. Our lives are less stressful by being members of this church. ${ }^{106}$

\footnotetext{
${ }^{104}$ Rev. Ugochuwku. Personal Interview in Jan 2020.

${ }^{105}$ Catherine Ekwueme. Personal narrative after a Sunday Devotional Service in Jan 2020.
}

${ }^{106}$ Chioma Ukaoha. Personal interview after a Sunday service, Nov 2019. 
The point of the discussion thus far is that the tradition of worship of the RGCC offers scope for the Nigerian members to express a sense of their Nigerian ethnic identities outwardly.

\section{Healing and Deliverance Hour/ Service}

The healing and deliverance tradition of the RCCG in Miami is another ritual context the allows for the performance of "Nigerianess" in Miami. This event takes place on the second Thursday of every month at $8 \mathrm{pm}$. The goal of the service is to provide deliverance and support to members with spiritual problems. Members are also encouraged to invite people who they think need spiritual help. The duration of this program is long as it begins at $8 \mathrm{pm}$ and ends at midnight. This allows time for the long prayer and deliverance activities that take place. The underlying rationale of this ritual form builds on indigenous Nigerian etiologies, which emphasize the supernatural causality of illnesses and social problems and recommend religious healing as a supplement to the mundane actions people take to resolve mishaps.

Participating in such rituals, therefore, gives the worshippers the feel of dealing with their problems in ways they consider culturally appropriate. In How to have a Healing Ministry without Making your Church Sick, the author, Peter Wagner discusses the miraculous and healing activities of Pentecostal churches in Nigeria. The story of two infected persons who were healed, and who later became Christians injected new life into Pentecostalism in Nigeria. ${ }^{107}$ According to Nigerian Pentecostal discourse, the devil had usurped the power to heal until the Pentecostals appeared on the scene and,

107 Wagner, C. Peter, in Ayuk's Essay, How to Have a Healing Ministry without Making Your Church Sick (Ventura, CA: Regal Books, 1990), 192. 
through the power and manifestation of the Holy Spirit, were able to deliver people from demons and dangerous ailments. I shall describe one of the Healing and service programs of the RCCG I attended.

It was the second Thursday of January 2020. The service started immediately at $8 \mathrm{pm}$. A member of the prayer warrior group led the opening prayer. The prayers were mostly of thanksgiving to God for allowing us to gather for service. We also invited the Holy Spirit to come and take control of affairs during the program. The prayer lasted five minutes before the praise and worship session began. This session was led by the choristers who sang and danced in accompaniment with the singing and the musical instruments. The members were all on their feet. The members were encouraged to" praise and dance unto the Lord as today is a day of healing and deliverance." The lead chorister reminded the congregation that the "walls of Jericho were made flat just because the children of Israel were singing and dancing. ${ }^{108 "}$ She said to us, "Right now, even if you have pain anywhere in your body, stand up and with faith, sing, and dance to the Lord, and I promise you that sickness must fail today in Jesus' name." This session lasted for twenty minutes, and miracles, healing, and deliverance were expected to start happening within this time of praise. The pastor took over the center stage after the praise and worship time. The topic of the day was "If your Faith could be the size of a Mustard seed." The pastor used the sermon to admonish "the people of God" to keep working on their faith. He reminded them, "it does not matter the severity, gravity, difficulty or length of your problem. What matters is your faith every day and every time." He reminded the congregation of the woman with the issue of blood in the Bible that Jesus healed in the twelfth year. He brought the message to an end by assuring the

${ }^{108}$ Healing and Deliverance Service 
congregation that their "problems are over today in Jesus's name." Then the prayer session ensued. The pastor led the meeting by mentioning different issues that needed prayerful attention and directing the members to pray. The room was filled with the noise of all worshippers praying loudly and in different dialects. Some people spoke in tongues. After the general intercessions, the pastor started mentioning a series of problems and called on the afflicted to the altar for "laying on of hands." Three members stood at the altar, raising their international passports and copies of their work visas applications. Some stood with pictures of relatives. There was also laying of hands on the sick, and prayers were said with emphatic gestures, shaking of fists, hitting of parts of the body, and behaving in ways outsiders might consider abnormal. After the pastor attended to different problems, there was a general altar call where everybody was anointed with olive oil and assured that they had been healed and delivered.

Describing this phenomenon in African Pentecostalism, Maxwell emphasizes how Pentecostal churches engage the resources of African indigenous cultures in pursuit of their agenda. They affirm the reality of the powers of indigenous gods, demons, witchcraft. They do not ignore but engage the primal contexts and renew the social system by critiquing and redefining possession, branding all as evil. They do not end there; they provide an alternative, "white," clean possession by the Holy Spirit. Through transformational cultural response, African Pentecostalism becomes a new form of possession, replacing the old by deploying an identical mechanism." ${ }^{109}$ This cultural dimension of Pentecostal healing that Maxwell describes is one factor that makes

\footnotetext{
${ }^{109}$ Maxwell, David. "Witches, prophets and avenging spirits: the second Christian movement in north-east Zimbabwe." Journal of Religion in Africa/Religion en Afrique 25 (1995): 309.
} 
worshippers feel at home with the practice in Miami. For them, this is not only worship. Participating in it is performing culture.

A lady in her mid-twenties recounted her disappointment when she first attended an American Pentecostal church in Miami. She said, "Although it is a Pentecostal church, I did not feel that Pentecostalism. The church was still kind of dull, too dull for my liking. I also felt a little bit odd in their midst because I wanted to dance and pray the way a Nigerian prays and to be healed of something, anything. Their prayer points were also not related to my prayer points." What this lady was lamenting was her inability to perform her culture in the American church. A "cultural day" tradition invented out of the traditional American Thanksgiving ceremony, which offers the opportunity for members to dress up in their traditional ethnic attires; funerals, performed according to the ethnic traditions of the dead; and a practice modeled after an Igbo tradition, which involves mothers in the worshipping community role-playing as live-in- nannies for women who have just had babies in Miami, are among the RCCG, Miami practices that offer the scope for worshippers to perform their ethnic Nigerian cultures in the context of their Pentecostal tradition.

\section{Praise and Worship Service}

Nigerian Pentecostal Churches are known for their distinctive styles of singing choruses during devotional sessions called "Praise and Worship." Praise and worship sessions involve spontaneous singing, dancing, shouting, handclapping, speaking in tongues, and prophesying. Describing the nature of praise and worship in the Pentecostal traditions of Nigeria and explaining its appeal, Ayuk characterized Nigerians as people that adopt 
loud musical instruments, and their songs most times are formed according to situations at hand which are not witnessed in other churches in the host land. ${ }^{110}$

In the Miami portion of the RGCC, a day is set aside for the Praise and Worship program monthly. On this day, prayer is not emphasized. Instead, the participants simply sing, dance, sway, and perform any other bodily movements. The choristers and the pastor lead these activities. Every song they sing is believed to evoke collective, personal emotions, and memories. With the sound of the music, singing, people pray, dance, clap and cry, and the Holy Spirit, which is said to be in charge, makes worshippers speak in different tongues. I participated in most of these activities and can attest that the services are vibrant. One respondent described the praise and worship session as his best. He is a young man and seems as young as 25 years. For him, this is a day and time when he receives all his needs from God. He compared the service to the day that David danced in the temple, and the Lord blessed him. He said, "Today is the day that you become blessed, healed, favored just because of your heartfelt praises to God just like David or a day you could become cursed just like David's wife. David's wife," he went on, "was cursed because she saw David as a king humiliating himself in worship God."111

The songs were sung in different languages, just like I have mentioned before. They are sung in Igbo and Yoruba and also English. I noticed that most of the members have different countenance whenever a song was sung in Igbo or Yoruba. Participants appear to be more joyous, and most of the time, their dance steps changed. The changes

\footnotetext{
${ }^{110}$ Ayuk, Ayuk Ausaji. "The Pentecostal Transformation of Nigerian Church Life." Asian Journal of Pentecostal Studies 5.2 (2002): 189-204.

111 Anthonia Ugwunna. Personal Interview and Conversation after a Sunday Devotional Service in Dec 2019.
} 
in dance steps and countenance are what an observer would not fail to notice due to their conspicuousness.

Congregational singing, clapping, and dancing is typical of Pentecostal practice. However, from the description above, we see that there is a cultural side to this church's worship culture. The culture of Nigeria. The songs are mostly from the Nigerian Pentecostal tradition, the dance moves are culturally familiar, the languages and dialects are from different Nigerian ethnic groups. The tunes are not only familiar, but their lyrics also reflect indigenous Yoruba, Igbo, and other ethnic worldviews. Worshippers do not only recollect the worship culture they left behind, they also perform it and collectively participate in the moods generated. They feel home is not far away. Within the space in which they worship, these worshippers are recreating home even if only temporarily. This is not only a religious performance. It is essentially cultural. Religion is only providing the space for its performance.

\section{Itinerant Preachers}

One of the ways that the African Pentecostal churches offer the context for fostering connections between the homeland and the diaspora is through itinerant preachers. These are ritual agents or pastors from the home Church in Nigeria who visit extensions in the diaspora to preach and preside over healing and deliverance sessions. Members and relatives living in Nigeria come for visits to the church. Members in diasporas also extend a hand through the visitors when they are returning to Nigeria. I mentioned earlier that the relationship and exchange is not a one-way thing, where it only comes from Miami. The exchange goes both ways. Members at home also contribute immensely to peoples' life here. They do so through prayers and sending remittances. For instance, 
they send local food through these visitors. They also contribute to the social wellbeing of members in the diaspora. In December 2019, a pastor from Nigeria visited the Redeemed Church in Miami. He presided over the devotional session that day and even preached the sermon that day. After the address, he started into a lecture about events in Nigeria. His primary focus was on Boko Haram, the Islamic terrorist group, and how it's activities had plunged Nigeria into a chaotic state. There was a question and answer session during which concerned members of the Nigerian migrant community sought further explanations on the crisis and also volunteered suggestions on how the issue could be resolved.

To conclude the session, the visiting pastor led a more extended prayer asking God to intervene and rescue Nigeria from the impending disaster. Individual worshippers also led shorter prayers. As the prayers were going on, the pastor kept reminding the community of the need for them to continually pray on behalf of the homeland as the resolution of issues depended on God's mercy. The Nigerians in the United States are aware of the insecurity in Nigeria but do not understand it to be at the level that the pastor narrated it to be. When the prayers were over, the congregation contributed money that would be donated to a fund set up for people living in Internally Displaced Camps (IDP) camps in Nigeria. Members were encouraged to come back to the church the next day if they had anything to contribute later. The visiting pastor also invited the members of the church to send some gift packages through him to their relatives in Nigeria if they wanted to. Many people did send packages to relatives. In the course of the fieldwork I received many text messages announcing the arrival of guests from Nigeria or migrants who planned to visit the homeland. The announcements were intended to make the migrant community aware of the visitor or traveler's plans in 
case they would like to send gifts or greetings home through them. Sometimes relatives in Nigeria also send gifts, mostly food items, delicacies mostly, that are not available in the diaspora. This situation is one that the concept of simultaneity speaks to. The church has become a meeting point of the homeland and the diaspora. Through the church, people from the homeland participate in the lives of people in the diaspora and vice versa. So, from the data gathered, the church provides the basis for performance and living a transnational life through itinerancy of people living in Nigeria and vice versa. During the 2019 general election in Nigeria, though the church interceded in prayers inviting the Holy Spirit to intervene in the affairs of the state, the pastor of the church encouraged church members that are eligible to vote and could afford to travel home to do so. Members pointed out that, the encouragement from the church, both from the General Overseer in the Nigerian parish and here was the main reason behind their traveling home to participate in the last election. At one of the Sunday devotional Services, the churches were connected globally (live broadcast), and the GO encouraged all eligible Nigerian voters to return home and exercise their voting rights. Globalization is one of the ways through which linkage to the homeland while in the diaspora is maintained.

The theme that ties these examples I have offered above in this chapter is that the version of Pentecostalism, the RCCG in North Miami practices are so indigenized that they have furnished Nigerian migrants with what can be described as a miniature of the homeland. In the time and space that this "home away from home" offers worshippers, they are able to perform aspects of their Nigerian identities. This "home away from home" is also a meeting point of Nigeria and its diasporic extension in Miami, for people from the homeland and those from the Miami diaspora engage each other 
simultaneously either through physical contact, symbolically, or through modern media forms.

\section{Witnessing and Testimony Time}

Witnessing and giving testimony is an outstanding activity in the African diasporic Christian community. This is usually called a "blessing time." The belief is that when one testifies, he or she receives more blessings. Onyinah notes that "the leaders of the churches become aware of different needs of members such as unemployment, healthcare problems, immigration issues, lack of accommodation, and others through insights from testimonies." 112

In RCCG, testimonies are also one of the essential activities. The Pastor explained that "testifying what the Lord has done for you in the presence of the people of God shows God how grateful you are. It also puts the devils and demons that are the cause of your problem to shame. Giving testimonies also works as a faith enhancer. When the people of God watch and hear the testimonies, their faith is elevated. To cap it all, the prayers that people receive after they testify seal the miracles to become permanent". ${ }^{113}$ Almost an hour is devoted to the testimony. In this particular program, members testify to problems solved, illnesses healed, and plans accomplished. A striking evidence of the testimony on one of the days involved a man. He seemed to be in his mid-forties. His countenance was that of joy as he danced from his seat to the altar to testify. His testimony was that his mother back home in Nigeria had been sick for some

\footnotetext{
${ }^{112}$ Onyinah, Opoku. "Pentecostalism and the African Diaspora: An Examination of the Mission's Activities of the Church of Pentecost." Pneuma 26.2 (2004): 216-241.

113 Personal Interview with Pastor Onyinnaya in December 2019.
} 
time. She was taken to the hospital severely ill, but she did not get better. He advised his brothers at home to always take his mother to church as he believed that God would perform his healing miracles. He prayed for his mother persistently and called on some prayer warriors he knew when he was in Nigeria to intercede for her. On one of the healing and deliverance programs, he also stood in the gap for his mother. The pastor prayed and anointed him on behalf of his sick mother during one of the healing and deliverance services. After two days, he received a call from Nigeria that his mother had been healed. ${ }^{114}$ Numerous testimonies were shared, all giving praises to God and also thanking the Pastor for letting God use him to do mighty works in the lives of worshippers. At the end of the testimonies, the pastor prayed for the congregation, giving praise to God for the miracles and at the same time, binding the devil to never again inflict harm on "the children of God." Describing this phenomenon in Africa Pentecostalism, Maxwell emphasizes how Pentecostal churches engage the resources of African indigenous cultures in pursuit of their agenda. They affirm the reality of the powers of indigenous gods, demons, witchcraft. Through transformational cultural response, African Pentecostalism becomes a new form of possession, replacing the old by deploying an identical mechanism."115

It is important to note that out of the thirty-five persons I interviewed, nineteen of them first attended other American churches before they became members of the RCCG. Their reasons were that the American churches did not make them fulfilled as Nigerians

\footnotetext{
${ }^{114}$ Testimony in the church on Feb 15, 2020

${ }^{115}$ Maxwell, David. "Witches, Prophets and Avenging Spirits: The Second Christian Movement in North-East Zimbabwe." Journal of Religion in Africa/Religion en Afrique 25 (1995): 177-8
} 
and Africans generally. "They do not really understand what we believe in and the way we do things," 116 a lady said, describing how the leading pastor of the RCCG church "raised" prayer points about families back home in Nigeria, about insecurities in Nigeria and about the issue of residency in the United States for members who needed these. "Which American Pentecostal pastor will remember to raise these issues as prayer points?" she rhetorically queried. "This church and its leaders understand us and our needs because they know and understand who we are, where we come from and where we are going," 117 she concluded. The above example demonstrates clearly how this church provides members contexts within which they act their Nigerianness and, at the same time, establishing links with their homeland. Prayers intended to make life easier in the homeland offered in the church give members the opportunity to participate in the national affairs of the home spiritually.

\section{The Thanksgiving Service}

This is one of the activities that are carried out worldwide in all RCCG's parishes. It usually occurs the first Sunday of every month. "Just as the name indicates, it is a service of thanksgiving, worship, honor, and praise to God who has preserved us and our families all over the world, both at home and abroad. A special day to thank God for His providence and preservation against the whims and caprices of the evil ones in the past months and also in the months ahead," 118 a pastor explained to me at one time. For most members, the first Sunday of every month is a day to experience a special service.

\footnotetext{
${ }^{116}$ Emmanuel Agwuncha. Personal discussion on the phone.

${ }^{117}$ Blessing Ifeoma. Personal Interview after a thanksgiving Service in Jan 2020

${ }^{118}$ Rev. Onyinnaya's narrative about the thanksgiving service
} 
"Members celebrating birthdays, anniversaries, and other special events are allowed to give thanks to God with special dance offerings before everybody joins in the celebration," the pastor explained to me. On one of the thanksgiving events, I observed the entire ceremony. There was a lot of singing, dancing, and swinging. This time the songs were mostly praise hymns. Individuals, who had special events to celebrate, were invited to do so. A man and his family of fifteen were among the members that celebrated that day. The man was celebrating his 55th birthday, and he was also thanking God for bringing him and his family of fifteen to the USA with permanent residency. He and his family danced in front of the entire congregation for about three minutes. He had the opportunity to address the church. However, he seemed to search for words to express his gratitude to God and the pastor of the church. He testified that his good luck was a result of prayers by members of the RCCG in Nigeria and Miami. His mother is a member of the church. The prayer team prayed for them to be successful in obtaining their green throughout the fifteen years of the processing. Suddenly, "God did it"; and all of them were called for interviews and were all granted their permanent residency. When he finished talking, his wife took over the microphone and thanked the pastor. 3She said that had it not been for the prayers of church members, "we wouldn't be here at this moment." She also thanked the church for the help members offered them in settling to life in Miami. She mentioned how the church van that comes to pick the family had been of great help "because coming to the church would not have been easy for us, as we are a big family now settling down in a new environment." A few other people testified to special moments in their lives, and after the service, photographs were taken with the birthday celebrant, his family, and the entire church. The birthday cake was cut, and members went into the lobby to eat a meal of jollof rice (A Nigerian delicacy) and poff-poff (a special Nigerian snack). One of the respondents described this 
moment as one of the events she doesn't like to miss in this church. She is a woman in her mid-twenties, a nurse, and a Nigerian. She came to the USA at the age of ten and has traveled back to Nigeria just twice since then. For her, thanksgiving days at RCCG are days that "remind me of my Nigerianness. You see the way I dressed at church today, and I am so happy with myself. You know, other days of the week, I am busy with work, have on my work clothes, and hardly have time for myself. But on this particular day, I have all the opportunity to rock my African attire and come to church. I also enjoy our Nigerian delicacies. For a while now, I have the chance to eat Nigerian dishes in this church only, and that is one of the reasons I don't like missing church services like this one," she giggled.

\section{Cultural Day}

On this same Thanksgiving Day, members come to the service flamboyantly dressed in different African attires and styles. The men came with their native attires and hats. Hats are not Christianly; Christian men do not go into the church with hats. Pentecostals back this up with a verse from the Bible, 1 Corinthians 11:7, where the Apostle Paul spoke about men should not cover their heads in the church. In Nigeria, most ethnicities and cultural attires for men require the wearing of hats or turbans. Therefore, on the RCCG, Miami cultural day, men can come to church with their hats on. The women were not left out. They came all dressed, shining in bright colors of blouses and native wrappers (African costume) and their headgears. The kids were not left out either as their parents dressed them in colorful, flamboyant cultural outfits. As a Nigerian, I could identify different Nigerian tribes from their outfits. I identified Igbo, Yoruba, Efik, Idoma, Ibibio, and some Riverine outfits. The pastor narrated this occasion as not an international one like the thanksgiving service. This program was rather invented as a result of being in a 
foreign land. When we come to praise God for all he has done in our lives, we wear our different cultural outfits to remember where God has brought us from, where we are right now and where He is taking us. Though we wear different cultural outfits, portraying different ethnicities, all in this church also reminds us of "our oneness in Christ." Here we are all Nigerians and Africans with no difference. This occasion also helps our kids to identify who they are. Most of them do not even remember that they are Nigerians, but on days like this, when their parents dress in the cultural outfit and dress them likewise, it is a reminder that though they are here in the USA, they are Nigerians. Parents also saw this occasion as a very helpful one. "Especially for our kids!" one of the respondents acknowledged. He is a man of about fifty. To him, "the greatest part he loves about this program is that it makes the kids know who they are. This society can easily make one forget his identity, especially when most of these children are born here.

This ceremony commits to their memories that they came from some other place. Here, they dress Nigerian, and they eat Nigerian. You can see from the different foods that we are served here. My kids never forget the taste of the jollof rice, Ofe egusi ${ }^{119}$ and puff-puff ${ }^{120}$ that they eat every cultural day. I am happy that our pastor made this kind of celebration possible for us. We are able to worship God in our Nigerian way and at the same time, act as the Nigerians we are. Here we get physical, social, psychological,

\footnotetext{
${ }^{119}$ Nigerian sauce eaten with swallow (Very traditional delicacy)

${ }^{120}$ A type of Nigerian snack that is made with flour and yeast.
} 
economical and, most importantly a spiritual connection to Nigeria, Africa, and the whole world. Most importantly, we make heaven," ${ }^{121}$ he concluded.

Butticci defines these celebrations and Sunday services "as profoundly tied to the cultural element of the various groups' ethnic culture and identity. African migrants attend these churches proudly displaying their native cultural and spiritual regalia. The exhibition of African Pentecostals' religious and cultural identity takes place in the greatest magnificence of the elegant fashions of traditional African Sunday attires. They celebrate and re-state their spiritual and religious identity by praying, singing, dancing, casting away evil spirits, and dressing in a super mix of colorful African attires. ${ }^{122}$ The picture below shows how members identify themselves as Africans and Nigerians through the way they dress on cultural days.

${ }^{121}$ Samuel Onyido. Personal interview after the Cultural Celebration in church on the first Sunday of Dec 2019.

${ }^{122}$ Butticci, Annalisa. "10 Religion in Motion: A Missionary Narrative of Creativity and Survival from the Pentecostal Nigerian Diaspora in Italy." Religion on the Move! Brill, 2013. 203-221. 


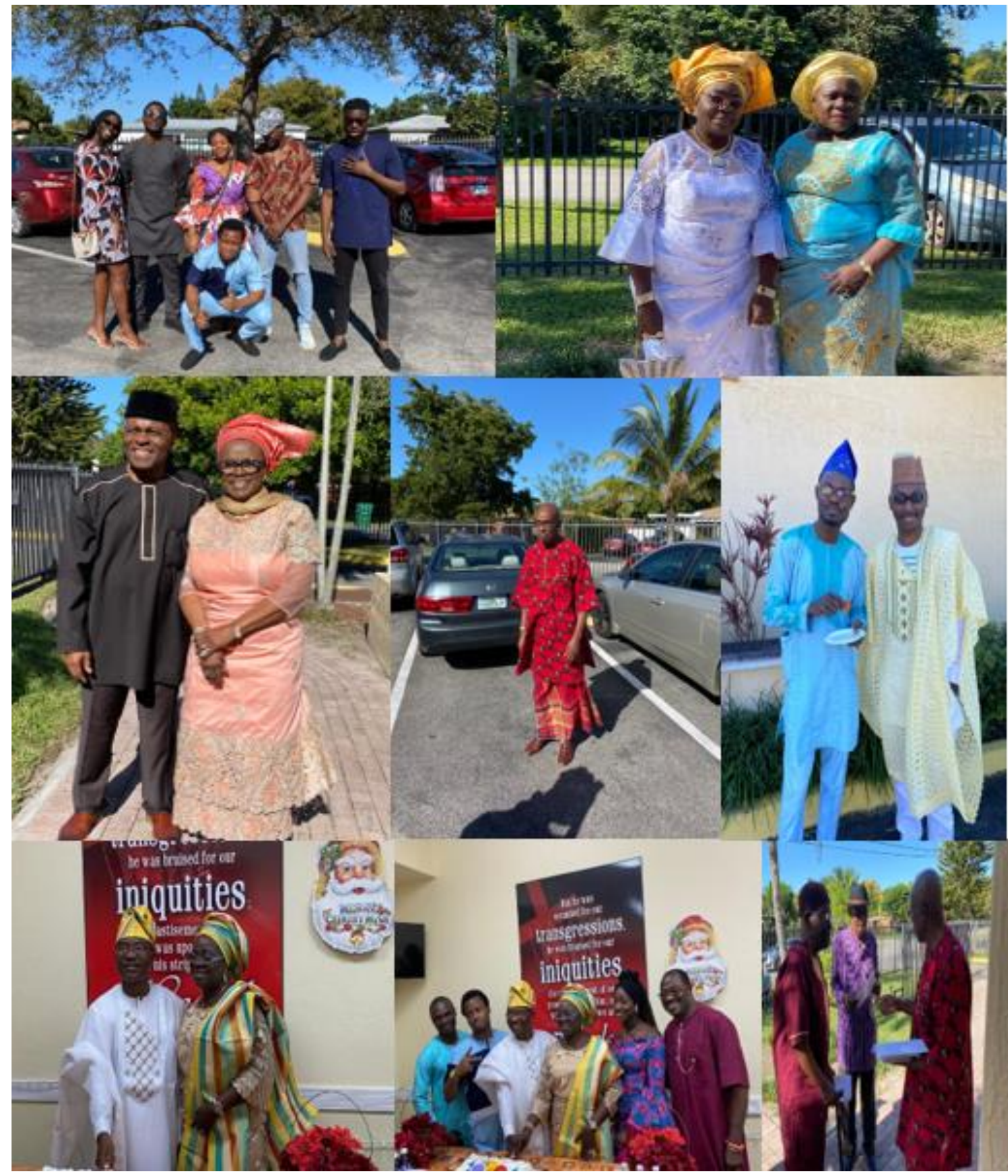

Figure 1: Traditional Attires on the Thanksgiving/Cultural day of the RCCG in Mami demonstrating one of the ways in which Nigerians perform their identity. Different Nigerian dishes are served during this ceremony.

\section{Early Morning Encounter with the Holy Ghost}

The RCCG Early Morning Encounter Service is distinct to the Miami parish. This activity is online and lasts for an hour, that is, from 6 am to 7 am. It begins on Mondays and end on Wednesdays. On the mornings of these days, members who are willing to 
participate, dial the available phone number and code to join the online prayer conference session. The participants' ring tones are muted as only the pastor's voice must be heard. He leads the prayer conference, mentioning different prayer points (the issues to be prayed for). The participants pray along with him.

The range of prayers did not include any personal prayer point. The pastor mentions general issues as prayer topics, for instance, pressing issues in Nigeria, Africa, and the United States. During one "Morning Service," the prayer point focused mostly on Nigeria's political situation. The pastor mentioned many difficult situations and invited participants to "ask God for mercy upon Nigeria." This was before the general presidential election in the country. The pastor asked the participants to ask God to intervene in Nigeria's situation and provide a leader who will care about "the needs of the masses." The participants also prayed to God to transform the USA into a nation that fears the Lord "in truth and spirit." We also asked God to intervene and avert extreme weather conditions in the United States. The threat of hurricane Dorian hitting some parts of the United States was imminent. I questioned the pastor about the rationale for this activity and whether it was international. "This program is a diaspora thing; most Pentecostal churches in North America and Europe have this program. The reason is because of the environment where we are, here, most people's jobs do not allow them to participate in church activities within the week. This program will enable them to pray with the brethren. This program facilitates the religious activities of members, and this is made possible through globalization," ${ }^{23}$ he lectured me before narrating, with excitement, how "during the past thirty years, this would not have been possible." "That

${ }^{123}$ Personal Interview with Rev. Onyinnaya at church premises. 
is why we have no excuse for not making sure that the word of Jesus Christ is preached to the whole world," ${ }^{24}$ he concluded. Globalization and the use of media and the ability of African Pentecostal churches to contextualize their religious mindset in the changing economic, social, political, and cultural settings they operate in, are evident here. Explaining the function of globalization in religion, Meyer says that in many settings, religion is of huge importance not only as a private experience and inner belief, but also as a connection to the sphere of politics and public affairs." ${ }^{125}$ She noted that democracy also facilitates the rise of Pentecostalism's involvement in the affairs of the state. ${ }^{126}$ Interestingly, most scholars see this ability to contextualize as a contributing factor to the rapid growth of Pentecostal churches in Nigeria, Africa, and beyond. ${ }^{127}$

Messages from the church publication department inviting members are always sent out, reminding them of the time and the reason to join in the early morning program. Sometimes, depending on the church's plan, the days and duration of the early morning encounter are changed.

Through activities like this, the RCCG in Miami, creates contexts for Nigerians to connect to back to home. They intervene in the affairs of their homeland through prayers and other spiritual activities. RCCG in Miami presents uses media and other forms of technology to achieve these goals. It is also important to note that captions in English

\footnotetext{
${ }^{124}$ Personal Interview with Rev. Onyinnaya on a Sunday Service.

${ }^{125}$ Meyer, Birgit. "Pentecostalism and globalization." Studying Global Pentecostalism: Theories and Methods (2010): 113-130.

${ }^{126}$ Meyer, Birgit. "Pentecostalism and Globalization." Studying Global Pentecostalism: Theories and Methods (2010): 113-130.

${ }^{127}$ Allan, Anderson. "An Introduction to Pentecostalism." Global Charismatic Christianity (2004)., 122.
} 
appearing on television screens translate sermons and other messages rendered in a Nigerian language or dialect. This is to enable the few visitors, who are of other ethnicities, understand what is said.

\section{Evangelization/ Proselytization}

Evangelization and proselytization are major characteristics of African Pentecostalism and Pentecostalism in general. Conceptual frames such as "reverse mission" or "remissionizing" capture the religious activities of African Pentecostal churches in the diaspora. ${ }^{128}$ While Thomas sees it as a redemptive mission which is overly ambitious, he noted that they play a role in providing the church members with the religious apparatus to navigate life in a foreign land. ${ }^{129}$ For the RCCG church, the mandate to preach the word was given by God and must be fulfilled. In Nigeria, Pentecostal churches, including the RCCG, always engage in evangelical services, despite the abundance of potential worshippers. One of the reasons for the above is what Ayuk describes as a Nigerian characteristic. He notes how, in Nigeria, everything in mundane life is controlled in the spiritual domain. Pentecostalism offers the context for the expression of this notion through its belief in spirits and in the power of the Holy Spirit to take control of life. ${ }^{130}$ Nevertheless, the economic and social conditions in Nigeria, the high rate of illiteracy in some parts of Nigeria, unemployment, poverty, bad

\footnotetext{
${ }^{128}$ Adogame, Afe. "The Redeemed Christian Church of God: African Pentecostalism." Global Religious Movements Across Borders. Routledge, 2016. 51-75.

129 Aechtner, Thomas. Health, Wealth, and Power in an African Diaspora Church in Canada. Springer, 2015.

${ }^{130}$ Ayuk, Ayuk Ausaji. "The Pentecostal Transformation of Nigerian Church Life." Asian Journal of Pentecostal Studies 5.2 (2002): 189-204.
} 
governance, poor healthcare facilities, ailments, and diseases are contributing factors to the rising appeal of Pentecostalism in Africa. People run to these Pentecostal churches as they offer and give them the promise of a good life through the belief in Jesus Christ and the Holy Spirit who can turn any situation around.

In the USA, this situation is different. A good percentage of Americans do not believe that the spiritual has anything to do with the physical; therefore, the African Pentecostal message is not easily accepted by them. However, Nigerians living in the USA have not changed their mindsets regarding the dovetailing of the mundane and the spiritual. In an interview with one respondent, who has lived in the USA for fifteen years, he told me of how he still believed that the spiritual controls the physical. "Don't you know that ancestral spirits from your forefathers, witches, and wizards from your village can even come to this land and attack you?" ${ }^{131}$ He rhetorically queried me. "That you have crossed seas, mountains, and oceans does not mean that those powers can no longer affect you. The only power that can subdue them is the power of God in the Holy Ghost. That is why you always must be in the midst of the children of God. Being among people with the same belief as you enables you to fight the devil and his agents. The devil, demons, they do not die, you can only subdue them. For the above reason, you need the constant power of the Holy Spirit to be in dominion," he concluded. ${ }^{132}$ At one time when I was involved in the evangelizing activity, we were all given copies of the evangelizing booklet, and we were divided into groups of three or four each. The pastor encouraged us to do the work of God and multiply souls for the kingdom of God. Each of the groups held hands and prayed that God should touch every soul that will see that tract. We went

\footnotetext{
${ }^{131}$ Ugochi, Onyekwelu. Personal Interview

${ }^{132}$ Ugochi Onyekwelu. Personal Interview
} 
ahead and shared the tracts to whomever we met on the street. We also placed tracts into all mailboxes on the streets. This activity took place after a Sunday service. The following Sunday, I expected to see a few new faces that would be as a result of the evangelism; however, I found none. I enquired whether this was always the case. The pastor's reply was, "The devil never wants people to know the truth to keep them in bondage, that is the reason why these people do not listen to the voice of God." "Nevertheless, we shall not despair in spreading the news of freedom, for that is what we are called to do,"133 the pastor added.

The Nigerian Pentecostalist discourse about foreign lands as spaces of disbelief is demonstrated on a prayer pamphlet of the RCCG. In that pamphlet prophecies for 2019 were declared. According to the information I gathered from members of the church, Americans, Cubans, and other ethnicities hardly attend the church. They may visit once, but never return to become members. The data reveals that Nigerians in the church invite other Nigerians and a few citizens of other African countries who may visit the church and decide to become members. This shows that though the RCCG's mission and vision are to evangelize other ethnicities and nationalities, they do not succeed always. The Nigerian churches established in the diaspora most times attract only Nigerians, which supports the claim that RCCG provides a context for these Nigerians to perform their Nigerianness. Figure two and three below demonstrate the message of assurance and promise that anyone who accepts the message of evangelism and becomes a member is assured of a successful life.

\footnotetext{
${ }^{133}$ Rev. Ugochukwu Onyinnaya. Personal Interview in Church Premises before an Evangelism activity in Feb, 2020.
} 
z was a cool evening before the winter. A the place was kicking his rubber ball all over the place. His father sat nearby enioying the cool breeze of the evening. Suddenly the the The the roof of a house and got stuck there. The 'clever' boy quickly got a long stick with which to dislodge his bail from the stick with ever because of his little stature, roon. Howwas near the house he covid not see the top the roof. When he moved back to a pint where he could see the ball on the a point would be too far from the house

After several futile efforts to reach his ball, the boy in desperation went to meet his father. With tears in his eyes he appealed to the oid man for help. The father looked at him sadly and said, "Didn't you see me here oll the tired and frustrated before coming to me for
hell help?

The boy did not say a word. The father got up and in a mone moy's ea you have learnt your lesson' he said, "I hop the father replied.

Many of us are like the boy in this story. W are true sons and daughters of God, born gain, sanctiled, holy living and tongue talking. Yet, we carry burdens about apparentiy ignorthe foct that our father in heaven is more "Nom solve all problems. Ephesians 3:20 says Now unto him that is able to do exceedingly abundantly above ail that we ask or thin according to the power that worketh in us."

Of course we know that he is able but we feel we should try our best first. After al we are 'strong' and 'wise' and 'experienced'. But did not 1 Peter 5:7 say that we shall cast all our cares upon $\mathrm{Him}$ because He cares for us? If we are to cast all our cares upon Him, then why are we still carrying part of the burden ourselves?
Could it be pride or ignorance? Could it be that we really do not trust him to do a good job if we surrender all our plans to Him? But did not, Psaim 37:5 encourage us to commit our way unto the Lord, trust Him and He shall bring it to pass? What about the additional witness of Psaim 55:22 and Proverbs 16:3? "Cast thy bur den upon the Lord and He shali sustain thee: He shall never suffer the righteous to be moved." and "Commit thy works unto the Lord. and thy thoughts shall be

What is it that worries you so much? You health? The doctor sasts yop is Thope for shall not de " Can the dead praise Him? Con those who go to the grave magnify Him? Is those who go tat can sing prise unto Him? Did $\mathrm{He}$ not say that $\mathrm{He}$ chose you so that you can praise Him? Why would you rather choose to believe a doctor instead of the Great Physician? Is anything too difficult for the Lord of al flesh?

Are you barren? is that your burden? Who made your womb? Is it not Jesus? If anything is wrong with that wamb, can he not mend it of replace it? Did not Luke 1:37 say that with God, nothing shal! be impossible? Is God a lar? Is He not the One who said, "be frutiff' and multiply.." in Genesis 1:28? Has he changed His mind? After all, He said in Isaiah $40: 8$. The grass withereth, the fiower fadeth, but the Word of God shall stand forever. Even if the womb is dead, at least it's not roten yet. Do you not remember the case of Lazarus, that he was not only dead but also rotten? Did not Hebrews $13: 8$ say that $\mathrm{He}$ is the same yesterday and today and forever?
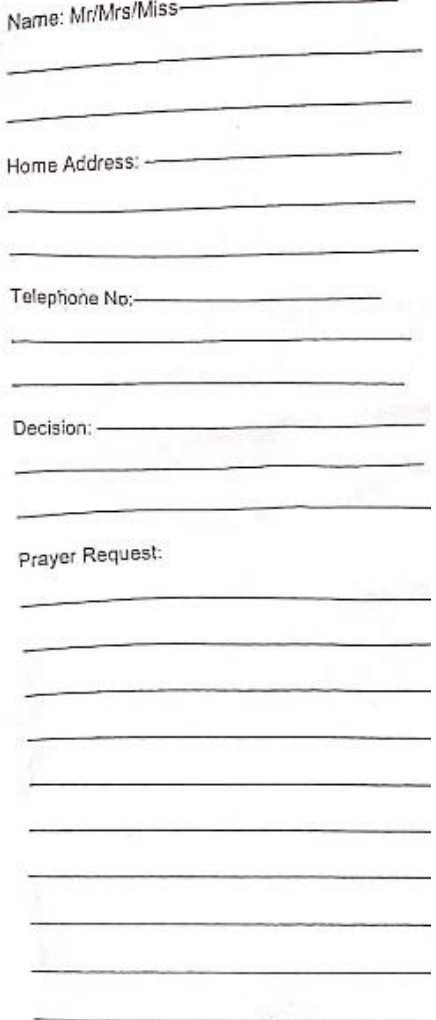

Figure 2: This is a flyer which the members distribute during evangelism. 
Is it your business that is giving you some concem? Do you think that He does not care for you too? Did not His word say that $\mathrm{He}$ wished ABOVE ALL THINGS that you PROSPER and be in health even as your soul prospers, III John 2? What do you under stand by "above all things?" is the supreme will of God Almighty that you should prosper? And if God wants you to prosper, how can your business fail? Unless of course you do not make Him your Partner or maybe He is your Junior Partner!

Brothers and sisters let God help you. Bring your problems to Jesus and hands off? That songwriter says it well:

"What a friend we have in Jesus All our sins and grief's to bear. What a privilege to carry,

Everything to God in prayer,

Oh what peace we often forfeit,

Oh what needless pain we bear,

All because we do not carry.

Everything to God in prayer."

If you are now ready to accept Jesus in your life, fill this form and send it to us after saying this simple prayer.

Lord Jesus, come into my life.

I accept you as my personal Lord and Savior. Come and forgive my sins. I believe you are the Son of God. I am born again, in Jesus Name, Amen.

Please join us for church services at the address below:

The Redeemed Christian Church Of God Victory Parish Miami

\section{NW 5 th Ave}

Miami, FL 33169

Tel: 7864280078

E-mail:

rccgvictorymiami@bellsouth.net

Sundays (Worship Service): 10:00am-12:30pm

Wednesdays: (Prayer \& Bible Study): $7 p m-8: 30 p m$

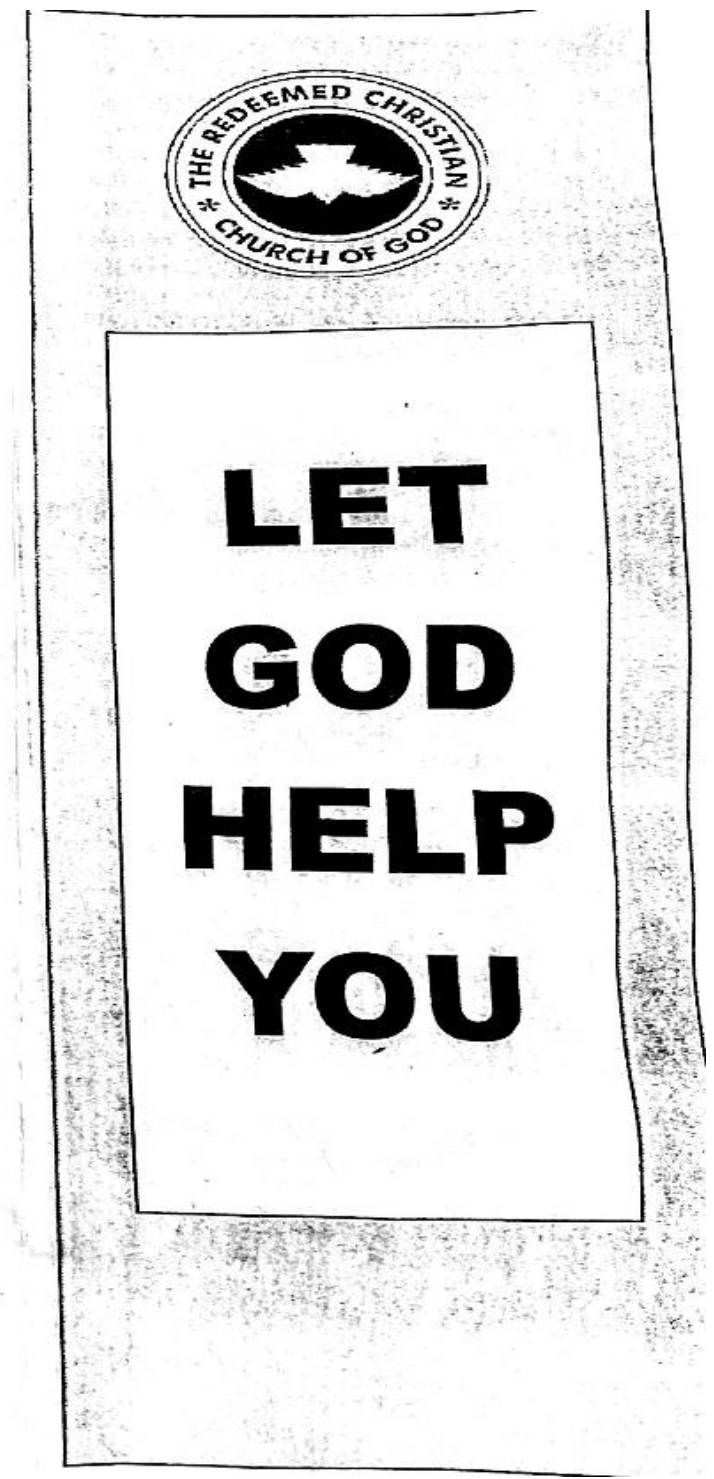

Figure 3: Continuation of Figure 2

\section{Child Dedication/ Funeral Assistance}

Child dedication is a cultural practice among all ethnicities in Nigeria. African

Pentecostalism has also been noted to appropriate some African cultural elements. The

child dedication is one of these. In RCCG, Nigeria, or abroad, this ceremony is an

important one. Unlike the mainline churches who may baptize the baby as a form of initiation into the fold, the RCCG performs a religio-cultural ceremony for newborn and 
their families. In Nigeria, the newly born is christened or named on this day. However, this is different in the United States.

In the United States, the baby is named at the hospital or birth facility for record purposes. During one of such events I witnessed, the couple that had the baby came to the church in colorful outfits befitting the occasion. The participants who showed up for this event were more than those who would attend a regular Sunday service. The couple invited some friends and well-wishers who were not members of the church. Towards the end of the devotion, a special moment was set aside for the couple and the baby. The choir led in the singing of praises as the couple was ushered to the altar with the baby. The invited members and the entire congregation followed suit. Offerings were deposited in the offertory box. After singing and dancing joyously for about five minutes, the pastor took over the microphone and invited just the couple to go up to the pulpit. The pastor beckoned to the mother for the baby and the baby was handed over to him. He started giving thanks to God for blessing the family. At a point, he paused and asked for the name of the baby, and the father replied, "Chioma."134 The pastor continued praying, naming the baby "Chioma" in "the name of the Father, the Son, and of the Holy Spirit." He declared words of exhortation on the baby in this manner, "Chioma, you will be a child of God. You will be a child that will make her parents proud. You are an exceptional child, and you will always hunger and thirst for the things of God." As he uttered these words, the congregation and the parents responded "Ameeeen"! When it was all over, the pastor handed the baby over to the mother, and the choir started into a song while the couple and the baby went back to their seats. The pastor announced that after the service, friends, and well-wishers, as well as members of the church, should not

\footnotetext{
${ }^{134}$ Igbo name of a newborn baby girl meaning (Good God)
} 
be in a hurry to go home as there were refreshments for them. This is a typical Nigerian way of naming a child. The parents of the baby explained that they had to give the baby an English name in the hospital and had to reserve the Nigerian name for the baby dedication. For Igbos, the baby has no name until the "naming day"135 which has been re invented as the dedication day in the RGCC in Miami. The pastor explained, "here we have to obey the law and at the same time, perform our culture." Among the Igbo and every other ethnicity in Nigeria, every name has a meaning. ${ }^{136}$

Likewise, in the case of the death of a member or the relative of a member, the church offers support to the bereaved families. Traditionally in most Nigerian cultures, when a death occurs, families and friends are told. Families and friends play a huge role in the consolation of the bereaved. It is a communal tradition. In some parts of Nigeria, relatives take turns to visit the bereaved. This is to help distract the bereaved from the pain of death until the last funeral rites are performed. There is a Nigerian belief that "once a corpse is buried, the pain of death becomes less." The support, however, is not only moral support. Relatives offer financial, economic, and social support to the bereaved family. This helps in the organization of the funeral. In the case of the RCCG Miami, when situations like the death of a member or a relative occur, the different church groups come together to support the bereaved family. They are involved in the moral, psychological, and social support of the bereaved families. Contributions and donations are made for families both in South Florida and in Nigeria. This depends on

\footnotetext{
${ }^{135}$ A day on which most Nigerian tribes perform a traditional and cultural ceremony of naming the child. Relatives and friends of the parents gather together to celebrate with them and the elders og the clan take the newborn, pray and name them. Until this day, a baby is not called by any name.

${ }^{136}$ Personal interview with Chidima Ugonabu after a Mid-week service
} 
the economic situation or level of the family of the deceased here in Miami and back home. An example of a case during my fieldwork will shed more light on this.

The death of a member's mother was announced during a church service. The member's mother was living in Nigeria. The member was a single young woman of about forty years of age. She was a student at Florida International University. At the news of the mother's death, which was announced during the church service, members were encouraged to reach out to her in love. Immediately after the church service, all groups announced that there was going to be an emergency meeting. Each of the church groups had brief meetings and discussed ways to support the lady. People made pledges on the amount of money they would to contribute to support of the funeral. The "mothers" arranged visits to the woman's home. The mothers made a phone call immediately at the meeting to know the woman's schedule before deciding on how and when visits should be made. Because the funeral of the mother took place in Nigeria, the money donated was sent home to the bereaved family as the woman was not able to travel home because of visa restrictions. On the day of the funeral, a group of girls from the church (youth members) visited the woman and remained there throughout the period of the funeral ceremony.

The members of RCCG take this culture of support as one way in which they demonstrate their unique identity as Nigerians in the United States. One of the members narrated her feelings about the practice drawing on her own experiences. "I lost my mum five years after I got to the USA. In those five years, I did not see my mum, and one day I received a phone call that my mum was late. I was devastated. I was here all alone in the world, no boyfriend, no husband, no relative, all alone in the whole wide world. You cannot imagine what it is like to feel like you are all alone in the world. Guess what? 
church gave me succor. Once I called a member and told her because I could not reach the pastor immediately, calls started flowing through my phone." At a time, she paused and asked me, "have you ever seen a family that lost someone here?" I answered, "no." Then she continued in a sad tone, "I wish you had witnessed such. These people here, they do not have that culture of caring for one another. Here, people lose someone very close to them, and you see them all alone during the period of mourning. That, to me, is devastating! That is not how we do it. Then next thing I see, brother and sisters from this church all calling me to know when they can come to visit me. They visited with different kinds of gifts ranging from foods, drinks, snacks, and what have you. They made sure they prayed and consoled me, assuring me that all is well. My dear, I was able to get through that devastating period of loneliness and pain with the support of this church. I was able to travel home for the funeral ceremony because of the donation, contributions, and support that this church gave me. I do not know how to put this, but believe me, "this church is family and most of us here feel the same way."137

\section{Child Visitation}

Child visiting is a Nigerian cultural practice. This is a situation where the mother or any relative of a new mother or her husband comes to help take care of the new mother at the arrival of a baby. Relatives travel miles for this cultural visit. It is a common belief, especially in Igbo land (Nigerian tribe), that a new mother becomes depressed if no relatives visit her after childbirth. However, some situations make this difficult or impossible for some couples living in far-flung foreign lands. This is especially true of Nigerians in the United States since travel from Nigeria to the United States takes almost

\footnotetext{
${ }^{137}$ Ngozi Ihenacho. Personal interview at the church premises during a brief refreshment with Nigerian delicacies.
} 
twenty-four hours and can be costly. Not all couples can afford the cost involved in bringing someone from Nigeria to the United States. The women section of the church, known as "the Good Women," perform the postpartum caretaking role in Miami. Once a woman is delivered of her baby, the group meets and schedules different days of visitation to the home of the family of the newborn. The women share the roles of bathing the baby, nursing the mother, and offering help in any other way. They also contribute and present gifts to the family. The response I got from the women when I asked about how they started the program and how they feel about it were very similar. The women began this program when they started having many family members in the church. Being Nigerians and women, they knew that not all families could afford the cost of bring relatives from Nigeria to help "new mothers." Even when some families could afford this, immigration processes can make this impossible. So many relatives from Nigeria invited for child visitation had been denied a visa. "So, we had to start this program to help ourselves and make sure that the family is not left alone in this society," one woman said.

A woman said "The program lends a physical hand, on the way we help physically, but it also lends a religious and psychological hand. When we go to the families, we pray with them and make them not miss the Nigerian Child visit tradition. In fact, we fill the gap." 138 Many women demonstrated how happy they are with the program. A young lady of about 28 years said this program has made her not to be sad whenever she had a baby." When I had my first baby," she started, before adding "I was not a member of RCCG. The first two weeks of my child's birth was the opposite of

${ }^{138}$ Goddy Usman. Personal Interview on the phone. 
what should be expected. I was depressed throughout my postpartum stage because those were the moments I mourned my mother's death the most and felt lonely. When I became a member of this church and found out that they had this, I was very excited. I thank RCCG women for this innovation. The women really took care of my baby and helped me out of postpartum depression. Our ancestors knew that this is a very delicate stage for women and devised a way to help reduce depression." ${ }^{139}$ A recent report in a New York Daily discusses the lack of this culture in America, its effects on women and efforts American society is making to help women out of depression and anxiety during this period. ${ }^{140}$ Having noted that, it is evident that the RCCG church has provided the basis for these Nigerian traditions and cultures to be transported and performed in the United States.

\section{The Children Department}

The Old and New Testaments of the Bible have a place of authority in Pentecostal traditions. These words are divinely inspired and believed to contain an infallible rule for faith and conduct, which is needed to navigate through life. ${ }^{141}$ Therefore, the domain of parenthood is not an exception. The Pentecostal Christian sees the scripture as a parenting manual that instructs parents in the way they should nurture their children.

\footnotetext{
${ }^{139}$ Goddy Usman. Personal Interview on the phone.

${ }^{140}$ Shant, Shahrigian, "NYC to Provide New Parents with Free Home Visits to Adice on PostPartum Depression and other Health Mental Issues" New York Daily News. February 06/2020

${ }^{141}$ This is one of the recurring statements among members of Pentecostal churches. "Bible provides an answer to every question about life. The bible teaches everything about life."
} 
Central to this instruction is the counsel to communicate the knowledge of God to offspring, to raise God-fearing and upstanding members of both the church and society. ${ }^{142}$ One scripture that is mainly used to support this practice is Proverb 22: 6, “" train up a child in a way he should go: when he is old: he would not depart from it."143 Within the Nigerian context, this scriptural counsel is interwoven with cultural dimensions to produce a practice in which children are taken to special classes in Pentecostal churches.

The creation of a children's department in the RCCG Miami, is in keeping with the Pentecostal tradition. The children have a separate class where they are taught the ways of God. During my fieldwork, I participated in the children's class for the purpose of data collection. I observed two essential characteristics that reflect the performance of culture. The children are taught in the English language two times a month. The other two Sundays are dedicated to the Nigerian indigenous languages (Igbo and Yoruba). When I inquired into the reason for this, one of the teachers explained that, "it is essential to let our kids know who they are. Knowing who they are begins from speaking their language. This teaching in the church may not make them speak the Nigerian languages fluently, but at least it helps them realize that they are Africans. These kids are in the USA, but they are Africans. They belong to both spaces; therefore, these contexts play crucial roles in the ways they are nurtured and socialized."144

\footnotetext{
${ }^{142}$ Janice, McLean, "The Place of Second-Generation Youth in West Indian Pentecostalism in the Diaspora- New York city London" in Adogame, Chitanda and Bateye's, African Traditions in the Study of Religion, Diaspora and Gendered Societies. 2013, 115

${ }^{143}$ New International Version

${ }^{144}$ Rev. Ugochukwu. Personal Interview concerning the children's department.
} 
Another crucial observation I made has to do with the teaching about discipline. The children recite the Bible verse Proverbs 22: 6: " Train up a child in the way he should go, and when he is old he will not depart from it." ${ }^{145}$ They are also reminded of Proverbs 13:24, "Whoever spares the rod hates his children, but the one who loves their children is careful to discipline them." ${ }^{146}$ These verses counsel parents about disciplining their children. The pastor did not hesitate for a moment to tell me, "We have to raise our children in the African way. We correct our kids because we love them just the way the Bible says that 'he whom God loves, he chastises.' 147 He continued, "So, we must let our kids know that even if we have to spank them, we do so because we love them. God punished the Priest Eli because he did not fulfill his responsibility as a parent to his children, which made the children go astray. Read about this in the Bible, the book of 1 Samuel 2: 12 to end. As Nigerian parents, it is our responsibility to make sure that our kids turn out to be acceptable in society, both here and at home. They need to know that nobody can love them more than the way their parents, the church, and God loves them. $\cdots, 148$

An additional important observation is praying for Nigeria and Africa. The children pray for Africa, their countries, and the USA. A pastor explained, "In doing these, they see themselves as the future hope of their nations. If we do not teach them now, when do we do it? They will all grow up in the USA and never want to go back.

\footnotetext{
${ }^{145}$ New International Version

${ }^{146}$ New International Version

${ }^{147}$ Proverb 3: 12.

${ }^{148}$ Rev. Ugochukwu. Personal Interview at the RCCG” s office.
} 
This is not what we wish for, of course, we want to achieve what we came here for, and go back to make our nation a better place. It begins with us and teaching our kids these things in good time will help." ${ }^{, 49} \mathrm{He}$ was answering my question on why the children needed to be taught about their identity.

Adogame describes it as an exilic characteristic. Many Africans indicate their intention to return home at the sunset of their sojourn. He notes that this claim appears to be wishful thinking or a myth that mediates the uncertainty of the present situation which however serves as a source of hopefulness." ${ }^{150}$ Some parents who responded to the questions I asked about the church's activities for children felt that, "these children live in America, which is not their place of origin, and they grow up amid different cultural backgrounds. Many of us parents here want to set our kids apart by maintaining a distinction between our kids and the Americans, and the church helps us to do this. Our kids know that they are Nigerians and that there are values that are required of them." 151 Waters refers to this as a form of "separation," which is expressed in the formation of social organizations, especially religious organizations, in which the immigrants could control. ${ }^{152}$ The control allows them to create interlacing ties that reinforce parental authority and values.

${ }^{149}$ Rev. Ugochukwu. Personal Interview at the RCCG” s office.

${ }^{150}$ Adogame, Afe, "Raising Champions, Taking Territories: African Churches and the Mapping od New Religious Landscapes in Diaspora" in Trost's, The African Diaspora and the Study of Religion” 2007, 26.

${ }^{151}$ Mrs Azuka Udeh. Personal Interview at the RCCG' s office after a Sunday Service.

${ }^{152}$ Waters, Mary C. "Ethnic and racial identities of second-generation black immigrants in New York City." International Migration Review 28.4 (1994): 795-820. 


\section{Social Services}

The RCCG in Miami, Florida, provides a context for members to perform religious and cultural obligations. However, it also designs and offers programs and activities that help it to meet communal needs. The programs contribute positively to developments in the homeland as well as in the host community. The church does not overlook the less privileged in society, whether they are Africans or not. Donations are made monthly for the purpose of feeding the homeless, the poor within the church, people back in Nigeria, and members of the community. "Homeless people sometimes visit the church asking for help, and these resources are needed to take care of such occurrences. We do not only want to win their souls for the kingdom of God, but we also show them that we love them, and Jesus loves them too" 153 a pastor explained, stressing how this was as important as the evangelism that the church engages in. A special fund has been created to help finance this project. Members are also reminded always to bring whatever they feel they do not need any more at home. These are located in a store house and donated freely to the public.

The Church demonstrated its extending of a helping hand to the larger public in Miami during hurricane Dorian in 2019. An announcement was made at every church program reminding the members that victims of the disaster needed help. Members contributed gifts of money, clothes, shoes, foodstuff, and groceries. Support to members and non-members of the host community aids social integration and engagement.

Grillo names three options for migrants' survival in the host society, which are contingent on the strength of transnational ties. The three options are assimilation (here

\footnotetext{
${ }^{153}$ Ataka Eddy. Personal Interview on the phone in Jan 2020.
} 
and same), integration (here but different), and enslavement (here but separate). From the data I gather, RCCG Miami falls into the second category. ${ }^{154}$ Firstly, it extends its generosity not only to members of the church who are Africans or Nigerians, but also to non-members, and the general host society. It does this through evangelizing and charity programs. The social engagement encourages members of the church to integrate into American society. Secondly, RCCG's social involvement in the lives of people here and back home, enables it to function as a social support network, enabling it to create international ties.

\footnotetext{
${ }^{154}$ Burgess, Richard. "African Pentecostal Spirituality and Civic Engagement: The Case of the Redeemed Christian Church of God in Britain." Journal of Beliefs \& Values 30.3 (2009): 255-273.
} 


\section{CHAPTER 7}

\section{CONCLUSION OF THE THESIS}

This final chapter highlights the argument on which this project is established: that African Pentecostal traditions in the African diaspora facilitate transnational links between African immigrants and their home bases in Africa. These traditions also offer contexts that sustain the between and betwixt experiences of African migrants in the west in that African migrants in the west and Africans in the homelands participate simultaneously in each other's worlds through processes facilitated by Pentecostal traditions in the Diaspora. These issues have received limited scholarly attention and my goal was to help fill this gap.

RCCG's mission in Miami is evangelizing the world and building a multicultural congregation. The Church's multiracial and multicultural aspiration is partially driven by the vision to have a member of the church in every family of all nations and the divine promise given to the founder that the church would spread around the world and remain till the second coming of Christ. ${ }^{155}$ These efforts are be seen in the activities that the church performs. However, the RCCG's Miami membership remains predominantly (99\%) Nigerian, with only $1 \%$ of other African ethnicities. Adogame identifies "a lack of cross-cultural appeal and the tendency of African migrants to interact only with fellow Africans as the main barriers towards the realization of a multi-racial group Pentecostal agenda. ${ }^{156}$ One of the obstacles to the successful integration of members of the

\footnotetext{
${ }^{155}$ RCCG Miami Bulletin. Dec, 2020.

${ }^{156}$ Adogame, Afe. "Contesting the Ambivalences of Modernity in a Global Context: The Redeemed Christian Church of God, North America." Studies in World Christianity 10.1 (2004): 25-48.
} 
community could be a result of RCCG's maintenance of specific cultural and religious beliefs and traditions, such as styles of evangelism, prayer, healing, and preaching which are typical of the church's Nigerian provenance. But this is so because the driving force behind Nigerian migrants' quest for a church in Miami is a space where they can create and perform their "Nigerianess" in varied ways

\section{Summary of Findings}

I also tie together the themes around which I have organized my chapters. The RCCG began as a result of the religious need of Nigerian immigrants in the United States. These groups of Nigerians wanted a Nigerian church despite the presence of several other churches in the United States. Convinced that their religion was essential to their success, adaptation, identity maintenance, and sustenance in the United States, the Nigerian migrants transported their Nigerian Pentecostal beliefs and practices to South Florida.

My study found out that the religious, political, economic and socio-cultural conditions in which Nigerian migrants find themselves in Nigeria before migration and upon arrival in the United States influence their religious involvement significantly. The Nigerian religious and cultural elements, which are a part of the RCCG Miami tradition allow Nigerians to perform and act their identities. While these cultural elements have less significance for worshippers in the homeland, they have become very crucial in Miami, as signifiers of an African religious form offering opportunities for Nigerian migrants to perform their Nigerian cultural practices. Experiences back home before sojourning to the United States nurse the need for a Nigerian church while the desire to 
maintain and sustain their uniqueness and that of their offspring in the United States makes the need more pressing. My study also found out that many Nigerian migrants view American churches as lacking in the area of meeting not only their spiritual needs but also their cultural, social, and economic needs as well. Using the RCCG Miami as a case study, I show how the need to meet their cultural and religious needs hastened the migrants' initiation of a home fellowship that later evolved into the RCCG Miami. The study also demonstrated that the RCCG serves as a link between Nigerian migrants and their homeland. Both groups are connected through the church's activities. The RCCG offers a context for Nigerians to perform their civic and social responsibilities while living in the diaspora. The church thins the line between Africa and the United States through the programs and activities it organizes. 


\section{Bibliography}

Books and Journal Articles

Adekola, Moses Akinwumi. The Redeemed Christian Church of God: A study of an Indigenous Pentecostal Church in Nigeria. Diss. Ph.D. Thesis, Department of Religious Studies. Obafemi Awolowo University, Ile-Ife, 1989.

Adogame, Afe. "Raising Champions, Taking Territories: African Churches and the Mapping of New Religious Landscapes in Diaspora." The African diaspora and the Study of Religion. Palgrave Macmillan, New York, 2007. 17-34.

Adogame Afe. "Contesting the Ambivalences of Modernity in a Global Context: The Redeemed Christian Church of God, North America." Studies in World Christianity 10.1 (2004): 25-48.

Adeboye, Olufunke. Arrowhead of Nigerian Pentecostalism: The Redeemed Christian Church of God, 1952-2005." Pneuma 29.1 (2007): 24-58.

Anderson, Monica. "A Rising Share of the US Black Population is ForeignBorn." Pew Research Center 9 (2015).

Anderson, Allan. African Reformation: African Initiated Christianity in the $20^{\text {th }}$ Century. Africa World Press, 2001.

Anderson Allan. "African Pentecostalism and the Ancestor Cult: Confrontation or Compromise." Missionalia: Southern African Journal of Mission Studies 21.1 (1993): 26-39.

Anderson Allan. "An introduction to Pentecostalism." Global Charismatic Christianity (2004),122.

Aechtner, Thomas. Health, wealth, and power in an African diaspora church in Canada. Springer, 2015.

Asamoah-Gyadu, J. Kwabena. ""From Prophetism to Pentecostalism": Religious Innovation in Africa and African Religious Scholarship." African Traditions in the Study of Religion in Africa: Emerging Trends, Indigenous Spirituality and the Interface with Other World Religions (2012): 161.

Ayuk, Ayuk Ausaji. "The Pentecostal transformation of Nigerian church life." Asian Journal of Pentecostal Studies 5.2 (2002): 189-204.

Beyer, Peter. Religion in the Context of Globalization: Essays on Concept, Form, and Political Implication. Routledge, 2013. 
Birgit Meyer, "Pentecostalism and Globalization" in Allan Anderson, Michael

Bergunder, Andre Droogers, Cornelis Van Der Laan (eds) Studying Global Pentecostalism: Theories and Methods, (Berkeley: University of California Press), 121-122.

Burgess, Richard. "African Pentecostal Spirituality and Civic Engagement: The Case of the Redeemed Christian Church of God in Britain." Journal of Beliefs \& Values 30.3 (2009);255-273.

Burgess, Richard. "Pentecostals and Political Culture in Sub-Saharan Africa: Nigeria, Zambia, and Kenya as Case Studies." Global Pentecostal Movements. Brill, 2012. 15 42 .

Butticci, Annalisa. "10 Religion in Motion: A Missionary Narrative of Creativity and Survival from the Pentecostal Nigerian Diaspora in Italy." Religion on the Move! Brill, 2013. 203-221.

Butler, Judith, and Kirt Butler. Excitable speech: A politics of the performative. Psychology Press, 1997.

Bruni, Frank. "Faith Fades Where It Once Burned Strong." New York Times (2003):1 7.

Cabrita, Joel. "Anderson, Allan Heaton, An Introduction to Pentecostalism: Global Charismatic Christianity. Cambridge: Cambridge University Press, 2014. xii+ 331pp. Pbk. "PentecoStudies: An Interdisciplinary Journal for Research on the Pentecostal and Charismatic Movements 15.1 (2016): 97-99.

Chitando, Ezra, Afe Adogame, and Bolaji Bateye. "Introduction: African Traditions in the Study ofReligion in Africa: Contending with Gender, the Vitality of Indigenous Religions, and Diaspora." African Traditions in the Study of Religion, Diaspora and Gendered Societies. Routledge, 2016. 15-24.

Cox, Harvey in Kalu, Ogbu. African Pentecostalism: An Introduction (Oxford University Press, 2008), 8

Cox, Harvey. Fire from Heaven: The Rise of Pentecostal Spirituality and the Reshaping of Religion in the 21st Century (Da Capo Press, 2009), 259

David Martin, "The Global Expansion of Radical Primitive Christianity," in Kalu's, African Pentecostalism 2000, 21.

Denzin, Norman K., and Yvonna S. Lincoln. Collecting and interpreting qualitative materials. Vol. 3. Sage, 2008.

Elphick, Richard. "Christianity in Africa in the 1990s." International Bulletin of Mission Research 21.4 (1997): 183 
Ganiel, Gladys. "Pentecostal and charismatic Christianity in South Africa and Zimbabwe: A review." Religion Compass 4.3 (2010): 130-143.

Goffman, Erving. The presentation of self in everyday life. London: Harmondsworth, 1978.

Haller, Dieter, "Transcending Locality: The Diaspora Network of Sephardic Jews in the Western Mediterranean," Anthropological Journal on European Cultures 9/1: 3-31.

Hammersley, Martyn Ethnography. "principles in practice/Martyn Hammersley and Paul Atkinson." (2007).

Hollenweger, Pentecostalism, p. 1; see Anderson, Varieties, Taxonomies,' pp.13-29; Anderson, To the Ends of the Earth, pp. 4-9.

Isichei, Elizabeth. A History of Christianity in Africa: From Antiquity to the Present. Wm. B.Eerdmans Publishing, 1995, 179.

Knut Rio, Michelle, and Blanes, Introduction to Pentecostal Witchcraft and Spiritual Politics in Africa and Melanesia", Contemporary Anthropology of Religion, 2017

Kgatle, Mookgo Solomon. "African Pentecostalism: The Christianity of Elias Letwaba from Early Years until his Death in 1959." Scriptura: Journal for Contextual Hermeneutics $\quad$ in Southern Africa 116.1 (2017): 1-9.

Levitt, Peggy, and Nina Glick Schiller. "Conceptualizing Simultaneity: a Transnational Social Field Perspective on Society 1." International Migration Review 38.3 (2004): 1002-1039.

Levitt Peggy. "Conceptualizing simultaneity: a transnational social field perspective on society 1." International migration review 38.3 (2004): 1002-1039.

Levitt, Peggy. "You know, Abraham was Really the First Immigrant": Religion and Transnational Migration." International Migration Review 37.3 (2003): 847 873.

Lofland, John, and Lyn Lofland. "H.: 1995, Analyzing Social Settings: A Guide to Qualitative Observation and Analysis" (Belmont, CA: Wadsworth, 1995), 10.

Omoyajowo, J. Akinyele. Cherubim and Seraphim: The History of an African Independent Church. New York: NOK Publishers International, 1982.

Maluleke, Tinyiko Sam. "Of Africanised bees and Africanised churches: ten theses on African Christianity." Missionalia: Southern African Journal of Mission Studies 38.3 (2010): 369-379. 
Mojubaolu Olufunke and Elisha, Renne, "Women's Leadership Roles in Aladura Churches in Nigeria and the USA in Adogame, Chitanda and Bateye, African Traditions in the Study of Religion, Diaspora and Gendered Societies, 2013, 100 .

Minchakpu, Obed. "All Levels of Society in Nigeria Touched by Charismatic Revival." The Blessings Page: A Periodic Magazine of Spiritual Renewal (2000), 1-2.

Maxwell, David. "Witches, prophets and avenging spirits: The Second Christian Movement in North-East Zimbabwe." Journal of Religion in Africa/Religion en Afrique 25 (1995): 309.

Meyer, Birgit. "Pentecostalism and globalization." Studying Global Pentecostalism: Theories and Methods (2010): 113-130.

Nealon, Jeffrey T. "Between emergence and possibility: Foucault, Derrida, and Judith Butler on Performative Identity." Philosophy Today 40.3 (1996): 430-439.

Olupona Jacob and Regina Gemiggnani. African Immigrant Religion in America. New York: London, New York UP, 2007,4

Olupona, Jacob K. African religions: A very Short Introduction. Vol. 377. Oxford University Press, 2014, 4.

Ogbu Kalu, African Pentecostalism: An Introduction (New York: Oxford University Press, 2008),284- 285.

Okome, Mojúbàolú Olúfúnké. "Emergent African Immigrant Philanthropy in New York City." Krase and Hutchison (eds.) (2004): 179-91.

Onyinah, Opoku. "Pentecostalism and the African Diaspora: An Examination of the Mission's Activities of the Church of Pentecost." Pneuma 26.2 (2004): 216 241.

Schechner, R. Between Theaters and Anthropology. Philadelphia, Pennsylvania University Press, 1985.

Trost, T., ed. The African diaspora and the study of religion. Springer, 2007.

Turner, Victor Witter, and Richard Schechner. "The Anthropology of performance." (1988).

Ukah, Asonzeh Franklin-Kennedy. The Redeemed Christian Church of God (RCCG), Nigeria. Local Identities and Global Processes in African Pentecostalism. Diss. 2003. 
Van Dijk, Rijk A. "From camp to encompassment: discourses of Transsubjectivity in the Ghanaian Pentecostal diaspora." Journal of religion in Africa 27.Fasc. 2 (1997): 135-159.

Waters, Mary C. "Ethnic and racial identities of second-generation black immigrants in New York City." International Migration Review 28.4 (1994): 795-820.

Wacker, Grant. "Are the Golden Oldies still Worth Playing? Reflections on History Writing Among early Pentecostals." Pneuma 8.1 (1986): 81-100.

Wariboko, Nimi. Nigerian Pentecostalism. Vol. 62. Boydell \& Brewer, 2014.

\section{Online Sources}

Our History: The Redeemed Christian Church of God. http://rccg.org/who-we are/history/. Last Accessed 01/07/2020.

RCCG Open Door Parish https://rccgodlexington.org/ministries/ . Accessed 01/30 2.30 am.

RCCG Victory Parish Miami https://www.rccgvictory.org/ministries/ Accessed 01/31, 2020.

RCCG at 50, p.16. There is a verbatim reproduction of this text in Redemption Light, vol. 7, no.7, August 2002, 7.

Institute for Public Understanding of the Past, Performance and performativity https://archives.history.ac.uk/1807commemorated/media/methods/performance.html

Bill Nunnelley, "Adeboye Head of Worldwide RCCG Church to Speak at Samford University" Oct.23, 2014.

Ukpong, Donatus Pius. "The presence and impact of Pentecostalism in Nigeria." Posted online at: $\quad \underline{w w w . g l o p e n t} . \quad$ net/.../presence-and-impact-ofpentecostalism-innigeria (2006).

Murrell, Nathaniel Samuel. "African Immigrant Religions in America." Journal of African American History 93, no. 3 (Summer 2008): 46365.http://search.ebscohost.com.ezproxy.fiu.edu/login.aspx?direct=true\&db=hus\&AN= $\underline{50993136 \& \text { site }=\text { eds-live. }}$

The Structure, Administration and Finance of the Redeemed Christian Church of God in North America", Dallas, Texas; RCCG Headquarters 